Int. J. Dev. Biol. 51: 1-26 (2007)

doi: $10.1387 /$ ijdb.062189nh

Special Contribution

\title{
A history of normal plates, tables and stages in vertebrate embryology
}

\author{
NICK HOPWOOD* \\ Department of History and Philosophy of Science, University of Cambridge, U.K.
}

\begin{abstract}
Developmental biology is today unimaginable without the normal stages that define standard divisions of development. This history of normal stages, and the related normal plates and normal tables, shows how these standards have shaped and been shaped by disciplinary change in vertebrate embryology. The article highlights the Normal Plates of the Development of the Vertebrates edited by the German anatomist Franz Keibel (16 volumes, 1897-1938). These were a major response to problems in the relations between ontogeny and phylogeny that amounted in practical terms to a crisis in staging embryos, not just between, but (for some) also within species. Keibel's design adapted a plate by Wilhelm His and tables by Albert Oppel in order to go beyond the already controversial comparative plates of the Darwinist propagandist Ernst Haeckel. The project responded to local pressures, including intense concern with individual variation, but recruited internationally and mapped an embryological empire. Though theoretically inconclusive, the plates became standard laboratory tools and forged a network within which the Institut International d'Embryologie (today the International Society of Developmental Biologists) was founded in 1911. After World War I, experimentalists, led by Ross Harrison and Viktor Hamburger, and human embryologists, especially George Streeter at the Carnegie Department of Embryology, transformed Keibel's complex, bulky tomes to suit their own contrasting demands. In developmental biology after World War II, normal stages-reduced to a few journal pages-helped domesticate model organisms. Staging systems had emerged from discussions that questioned the very possibility of assigning an embryo to a stage. The historical issues resonate today as developmental biologists work to improve and extend stage series, to make results from different laboratories easier to compare and to take individual variation into account.
\end{abstract}

KEY WORDS: history of embryology, Franz Keibel (1861-1929), normal plates, normal stages, standards

Research on embryos is today inconceivable without normal stages, the pictures plus texts that define standard divisions of development. Developmental biologists so internalize these descriptions that a new embryo of a familiar species is almost unconsciously assigned to a particular stage. Like all standards that meet the needs of a community of users, normal stages tend to be taken for granted (Latour, 1987, pp. 251-254). They may be regarded with respect, even affection, but as tools are of lower status than results. Reprinting the Hamburger and Hamilton normal stages (Hamburger and Hamilton, 1951), the most-cited paper in chick developmental biology, an editor worried that commending "what is, after all, an organizational rather than an intellectual achievement" might "amount to damning with faint praise" (Sanes, 1992). The concern extends to the history of embryology. We have many histories of theories, experiments and even descriptions, but normal stages and the related normal plates and tables have been ignored (but see Corner, 1951; O'Rahilly, 1988; Hopwood, 2000). This article brings developmental biologists the first extended history of standard embryonic series of vertebrates (Hopwood, 2005).

To reconstruct the making of normal plates, tables and stages, we need to analyse each step, from the collection of specimens, through the production of drawings or photographs, to publication and reception. Criteria for the selection of representatives deemed normal and appropriately spaced have shifted in especially significant ways (Daston and Galison, 1992). At first, one series may look much like another, but by taking these routine practices seriously, we can recover a rich history of change. This allows us to see how the construction of standard series has responded to the contrasting demands of different kinds of embryology. It reveals further how normal plates, tables and stages have not just been shaped by, but have also shaped the science. 


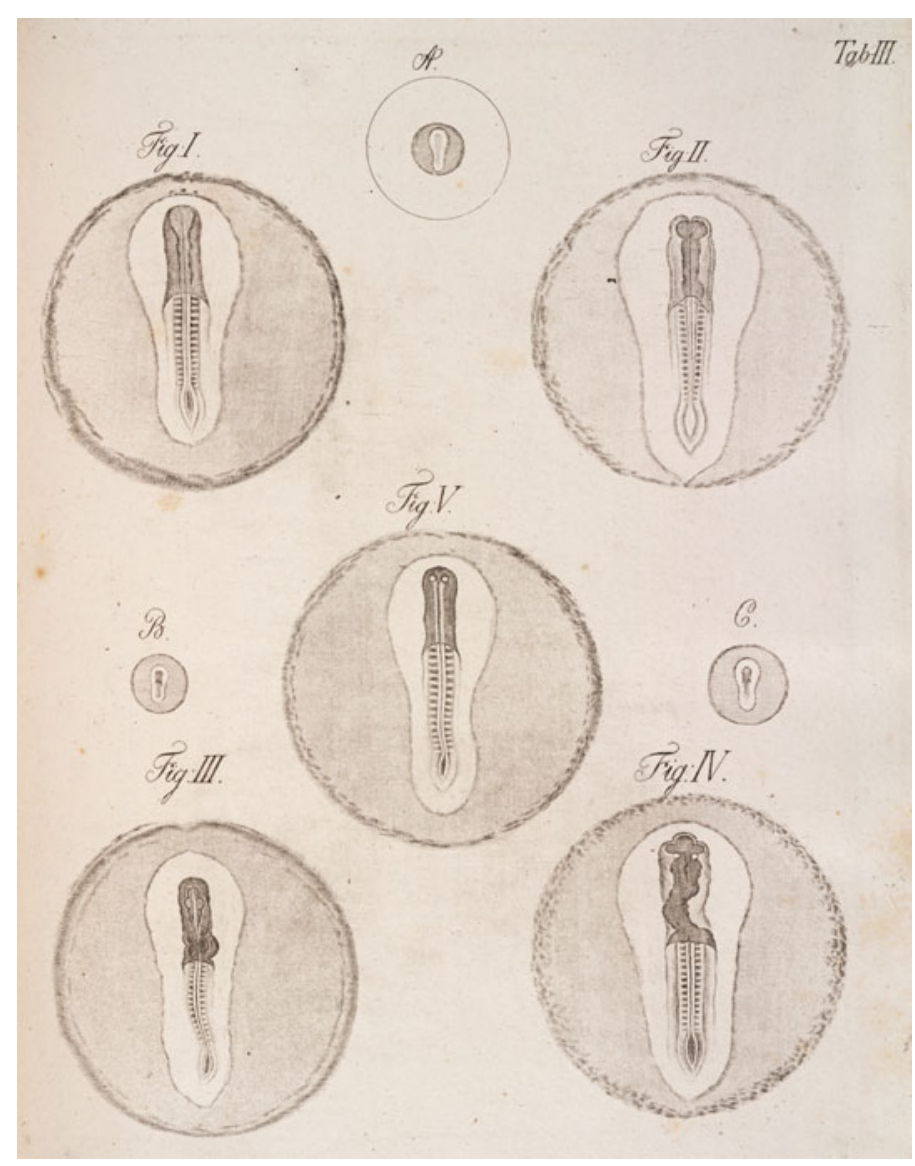

Fig. 1. Part of Christian Pander's foundational developmental series of the chick in the egg. Pander, a friend of von Baer, does not indicate how each "fetus" was selected. Images I and III show the dorsal aspects of the embryos seen in images II and IV from the ventral side; in the original A-C give the natural size of the embryos magnified in images I and II, III and IV and V. From Pander (1817), pl. III, by permission of the Syndics of Cambridge University Library.

The article is pivoted around the most influential set of embryological standards, the Normal Plates of the Development of the Vertebrates that were edited from 1897 by the German anatomist, Franz Keibel. It first introduces some theoretical and disciplinary problems raised by nineteenth-century embryology and the representational resources, in the form of newly-invented plates and tables, with which Keibel attempted to solve them. To understand how and why he created the major printed monument of comparative evolutionary embryology we need to reinterpret well-known troubles in the field as practical problems of staging within as well as between species. The resulting publication series mapped an embryological empire, but did not lead to a theoretical synthesis and so has been presented as failing (Gould, 1977, p. 174). Yet the plates were an institutional and practical success, forging a network within which the first embryological society was founded and becoming standard laboratory tools. After World War I, experimentalists and researchers on human embryos transformed the genre to suit their own contrasting demands. In developmental biology after World War II normal stages-reduced from complex, bulky tomes to a few easilyphotocopied journal pages_played key roles in organizing work on model organisms. Staging systems had emerged from a debate that questioned the very possibility of assigning an embryo to a stage.

\section{Ontogeny and phylogeny, series and stages}

To grasp the problems that Keibel's normal plates were launched to resolve, we need to trace the relations between ontogeny and phylogeny that had been established and challenged in the preceding decades (Gould, 1977). To appreciate the social pressures that made these problems urgent, we need to place the theoretical disputes in the inter- and intradisciplinary struggles that drove them (Nyhart, 1995). And to understand the resources on which Keibel would draw, we need to explore in practical terms how representatives were selected and arranged, within species and between them (Hopwood, 2000).

Embryology as we know it had been created in the decades around 1800 from investigations into generation, natural histories of monsters and anatomies of the pregnant uterus. It joined comparative anatomy as one of the two pillars of morphology, the new science of organic form. While anatomy was often at a loss to interpret adult structures, complex and obscured by function as they were, embryology claimed to show how diversity arose from simple, shared beginnings. Its most important institutions were the German universities, especially the institutes of anatomy and physiology. But from the late 1840s physiologists oriented towards physics rejected morphology as failing to seek properly causal explanations and claimed separate chairs. Embryology remained in the anatomical institutes, where special courses in human embryology became small but standard parts of the medical curriculum, and gained the newly-independent institutes of zoology as its other main home (Russell, 1916; Churchill, 1994; Nyhart, 1995; Duden, Schlumbohm and Veit, 2002; Hopwood, 2002; 2005).

Karl Ernst von Baer's Über Entwickelungsgeschichte der Thiere ("On the Developmental History of Animals"), though best known for its theoretical conclusions, began with practical advice on how to determine "individual periods of development" in the face of individual embryonic variation. This was necessary, because "[i]f one does not hold to such principles, then one can furnish a quite monstrous embryology, the individual determinations of which do not fit together at all." Von Baer divided "inequalities in the periodicity of development" into two kinds: "in the association of the phenomena" and "in the progress of development as a whole". The former were not very significant, but visible between less closely related parts; gut development was more tightly associated with the mesentery than the brain. "Much more variable", he wrote, "is the progress of development according to the duration of incubation and a real nuisance for the observer". Sources of variation included temperature, above all, and the age of the eggs. "Now, in order nevertheless to be able to determine times for the individual steps ..., I sought to determine a normal development", that is, "the most usual" under the "favourable conditions" he specified. Von Baer thus divided chick development into 21 comparable days (Baer, 1828, pp. 4-7).

Von Baer's contemporaries and successors proceeded in similar ways. They took account of predecessors, but since there was no great pressure to conform were free to set up whatever series or stages seemed best to suit the material and problems at 
hand. Divisions were variously based on age, length or other dimension and morphology, especially somite numbers. In general figures represent the degree of development in an interval without much discussion as to what made the embryos representative (Fig. 1). Large numbers of chick embryos allowed abstraction from individual specimens and even some consideration of normal variation, while scarce human specimens were studied case by case. For what is generally regarded as the first connected series through early human development, in 1799 the anatomist Samuel Thomas Soemmerring aimed to depict the "most beautiful" and so also least abnormal embryos from his collection of mostly aborted material (Fig. 2). Typical of atlas-makers until the mid-nineteenth century, he sought to see beyond mere individuals to represent types (Daston and Galison, 1992). Though for medico-legal purposes, such as determining the age of an aborted fetus, monthly descriptions or "characteristics" were used, sometimes in tabular form, anatomists tended to depict seriations, not formal stage divisions. For more advanced embryos, they followed separately the development of the different organs (Valentin, 1835).

Much of this embryological work was comparative-but only up to a point. It was hotly debated whether human embryos recapitulated the forms of all the major groups of adult animals, or whether the animal kingdom was divided into four separate types, within which development did not run in parallel but diverged. Similarities and differences were traced in the development and differentiation of the germ-layers. Yet key discoveries stressed unity and detailed comparison focused on individual organs (Russell, 1916, pp. 133-168; Gould, 1977, pp. 33-68; Appel, 1987; Lenoir, 1989, pp. 54-111). The major conclusion, that all vertebrates develop within a common type (Fig. 3), served primarily to justify the use of the chick and domestic mammals as surrogates for human development, the main medical and anthropological concern. The few pictures that compare whole embryos of different species are, by later standards, unimpressive (Hopwood, 2005, pp. 247-248).

From the 1860s Darwinists pushed to make comparison central. The Jena zoologist Ernst Haeckel generalized an evolutionized doctrine of parallelism as the 'biogenetic law' that individuals repeat in the course of embryonic development the most important changes through which their adult ancestors passed during the evolutionary development of the species: ontogeny, he taught, recapitulates phylogeny (Gould, 1977, pp. 69-114). In the absence of fossils, Haeckel assigned embryos, especially the early stages of the most primitive groups, a central role in recovering the history of life on earth. To bring the embryos of phylogenetically significant species back to landlocked European collections, his students founded marine stations, notably at Naples, and explored the globe (e.g., Semon, 1896; see also Raff, 1996, pp. 1-4).

The problem, Haeckel admitted, was that ontogenetic stages never corresponded exactly to ancestral ones. Just as repeated transmission and translation corrupted a text, so the phylogenetic record became more or less 'falsified' in ontogeny. He distin-

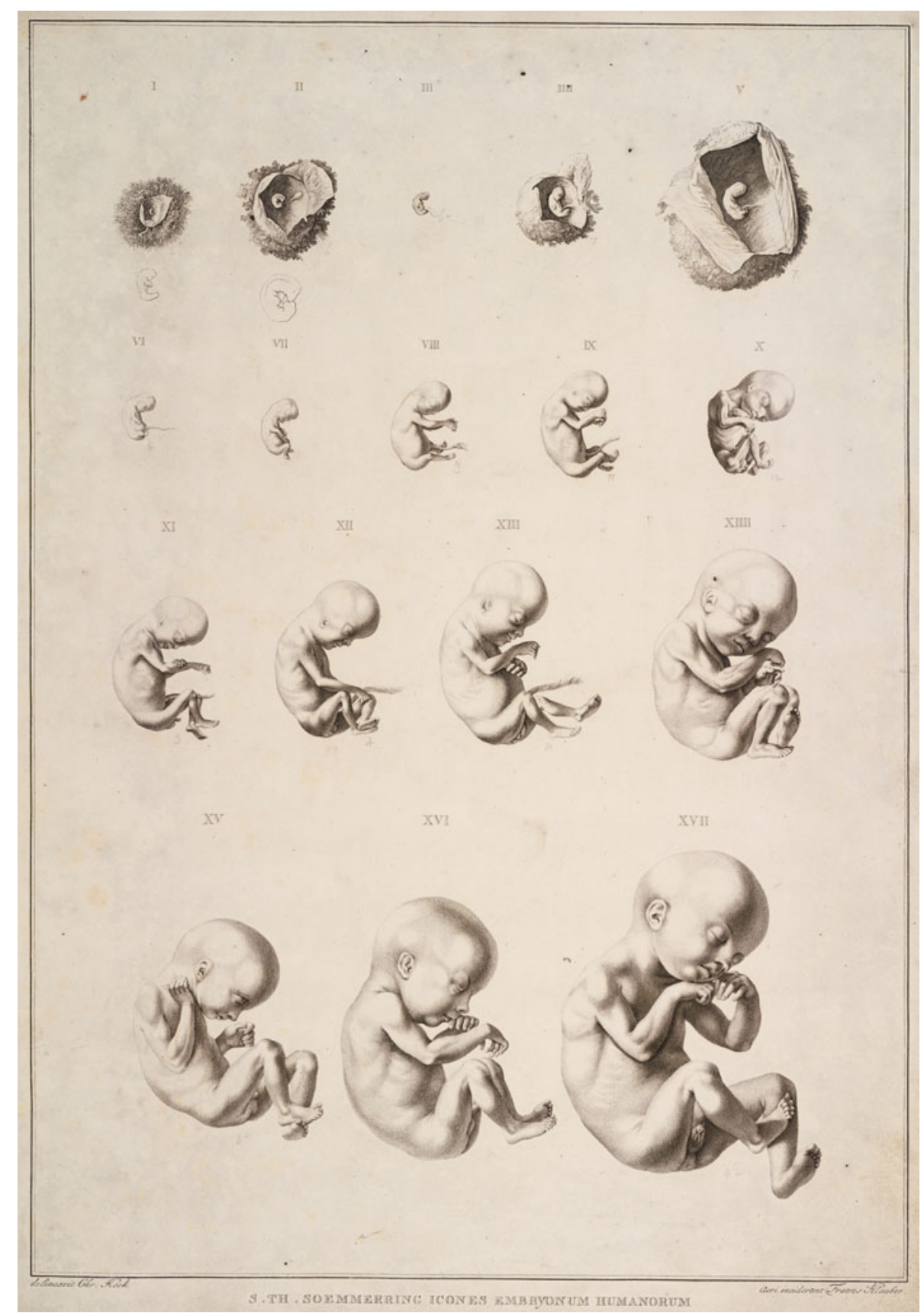

Fig. 2. Images of human development. Soemmerring estimated these embryos as ranging from the third or fourth week to the fourth month. Engraving by the Klauber brothers after drawings by Christian Koeck, from Soemmerring (1799), pl. I, by permission of the Syndics of Cambridge University Library. 


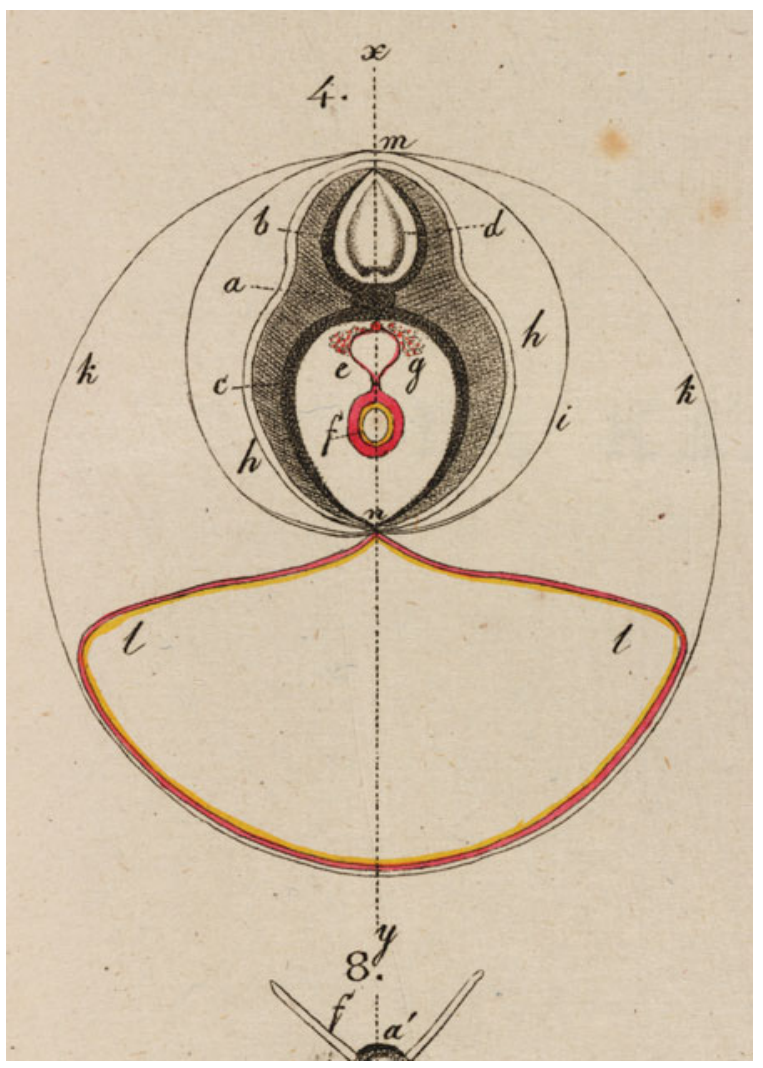

Fig. 3. The vertebrate type. Karl Ernst von Baer's "ideal vertical crosssection of the embryo of a vertebrate". Engraving from von Baer (1828), pl. III, fig. 4, by permission of the Syndics of Cambridge University Library.

guished the faithful 'palingenesis' from the corrupting 'cenogenesis', with its major mechanisms, 'heterochrony' and 'heterotopy'. Heterochronies were changes in the timing of development; for example, in vertebrate embryos the heart appeared much earlier in relation to the other organs than it had in evolution. Heterotopies were changes in place, especially shifts of cells from one germ-layer to another: the sex glands arose in the mesoderm, but must originally have developed from one of the two primary germlayers (Haeckel, 1874, pp. 634, 717; 1875, pp. 409-416).

The new physiologists had abandoned embryology as intractable with their physical methods, but from the mid-1860s the Basel, later Leipzig, anatomist Wilhelm His attempted to approach chick development as a problem in analytical mechanics (and also set up numbered stages that, he commented, corresponded well to Pander's divisions). His became Haeckel's most uncompromising early opponent. Though not against evolution, he shared the physiologists' withering view of morphological explanations and rejected Haeckel's subordination of embryology to the construction of evolutionary trees. His countered with a mechanics of development, driven by the bending and folding caused by unequal growth (His, 1868;
Hopwood, 1999).

Haeckel and His developed rival visual languages that promoted syntheses of opposing kinds. Plates in the semi-popular books that from 1868 brought Haeckel's Darwinist system to the reading public give unprecedentedly comparative surveys of whole vertebrate embryos. By 1891 he offered three rows for developmental stages and, spread over four plates, 14 columns for species (Fig. 4). Yet embryological specialists found phylogenetic and ontogenetic series harder to align. His and others accused him of making the earliest stages look more similar than they really were and of inventing other illustrations. Haeckel's reputation was tarnished by charges of forgery, but he continued to inspire research (Gursch, 1981; Hopwood, 2006).

His, by contrast, deepened the anatomical description of development by introducing an effective microtome and pioneering techniques for reconstructing wax models from the sections (Hopwood, 1999; 2002). In the early 1880s, he applied the new methods to human embryology. Reacting against Haeckel's destabilization of this previously rather open field, he proposed demanding, specialist standards. The many rejected specimens included a human embryo Haeckel had deployed against him that His claimed-and eventually convinced his colleagues-was that of a bird (His, 1880; Hopwood, 2000). His began by optimistically dividing human development into stages (His, 1880, pp. 147-173), but exhaustively describing particular individuals made this hard. As he continued to analyse named embryos and arrange those he selected in series, he abandoned such abstractions and worked instead to set up "norms", that is, representatives of "the relations of form and size which define each stage" (His, 1882, p. 2). He eventually went back to usual practice in human embryology and, avoiding stages, simply arranged representatives in order (Fig. 5). But unlike Soemmerring His claimed nothing for his specimens beyond their status as probably normal, well analysed individuals. For this seriation he used the term Normentafel, or "plate of norms"; it would later either be kept in the German or translated as "normal plate" (His, 1885; Hopwood, 2000). There is some slippage in meaning here: norms were standards, but for human embryos recovered from abortions the main concern was to avoid abnormality.

Though His refounded human embryology as a somewhat separate line of work, a great deal of primarily comparative research continued. As long as the cenogenetic chaff could be separated from the palingenetic grain, the biogenetic law accommodated exceptions so readily that it could never be disproved (Gould, 1977, pp. 167-206). But embryologists' conflicting choices made its application appear arbitrary and this left them vulnerable to attack from disciplines that favoured other evidence of evolution. Faced with Haeckel's exaggerated claims for ontogeny, even his Darwinist comrade-in-arms, Carl Gegenbaur, began asserting the rights of comparative anatomy. By the late 1880s he was arguing that cenogeneses could be

Fig. 4 (Next page). Comparative plates of vertebrate embryos in Ernst Haeckel's semi-popular Anthropogenie. Lizard (E), snake (A), crocodile $(K)$, turtle (T), chick (G), ostrich (Z), opossum (B), pig (S), deer (C), cow (R), dog (H), bat (F), rabbit (K) and human (M) are shown at three developmental stages, "very early" (I), "somewhat later" (II) and "even later" (III). These four lithographs by Adolf Giltsch after Haeckel's drawings provided the most vivid survey of comparative vertebrate embryology when Franz Keibel was engaging with the biogenetic law. The fourth edition was less provocative than the earlier ones, but these pictures still included much that was controversial. From Haeckel (1891), pl. VI-IX, by permission of the Syndics of Cambridge University Library. 

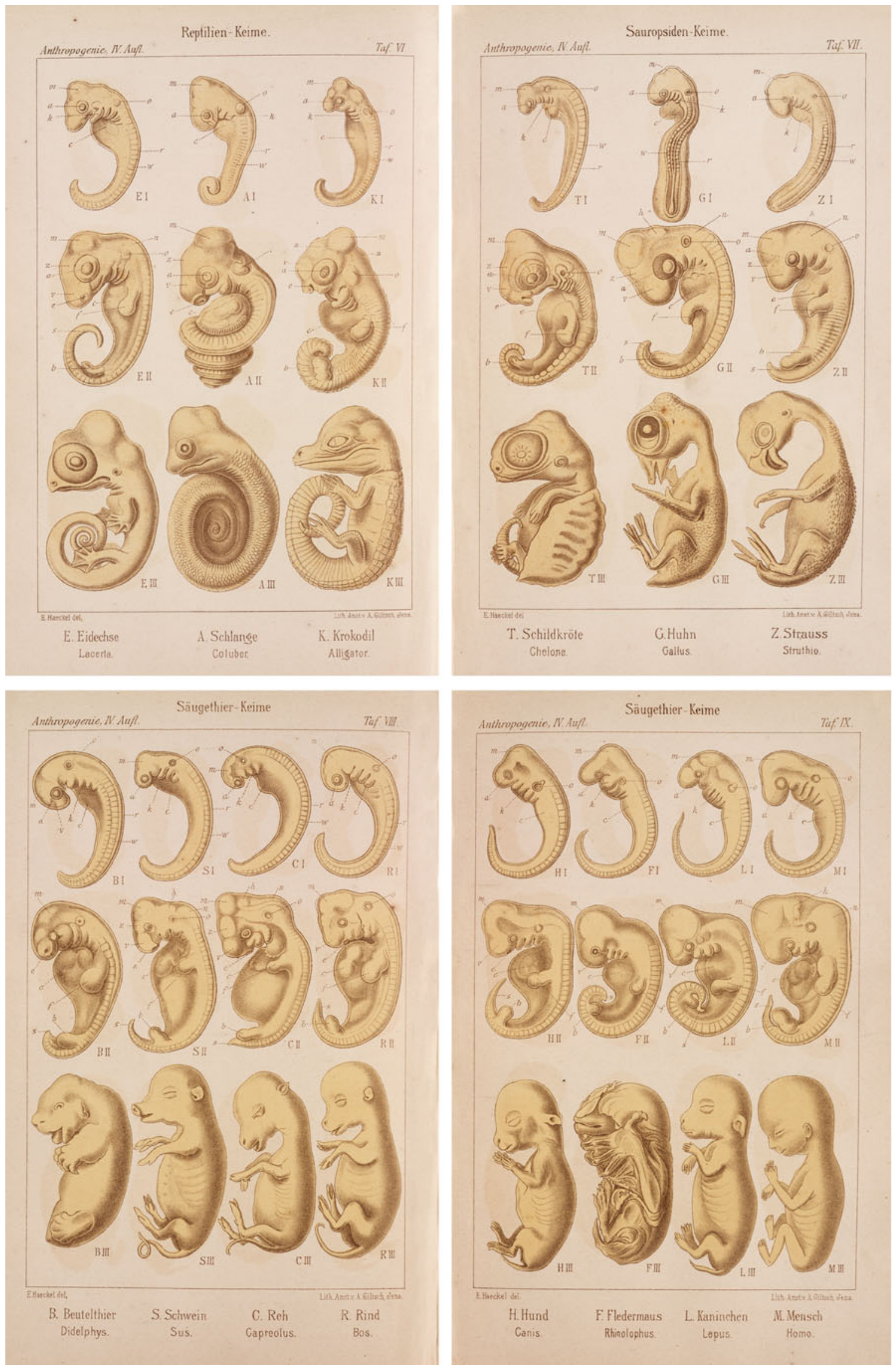


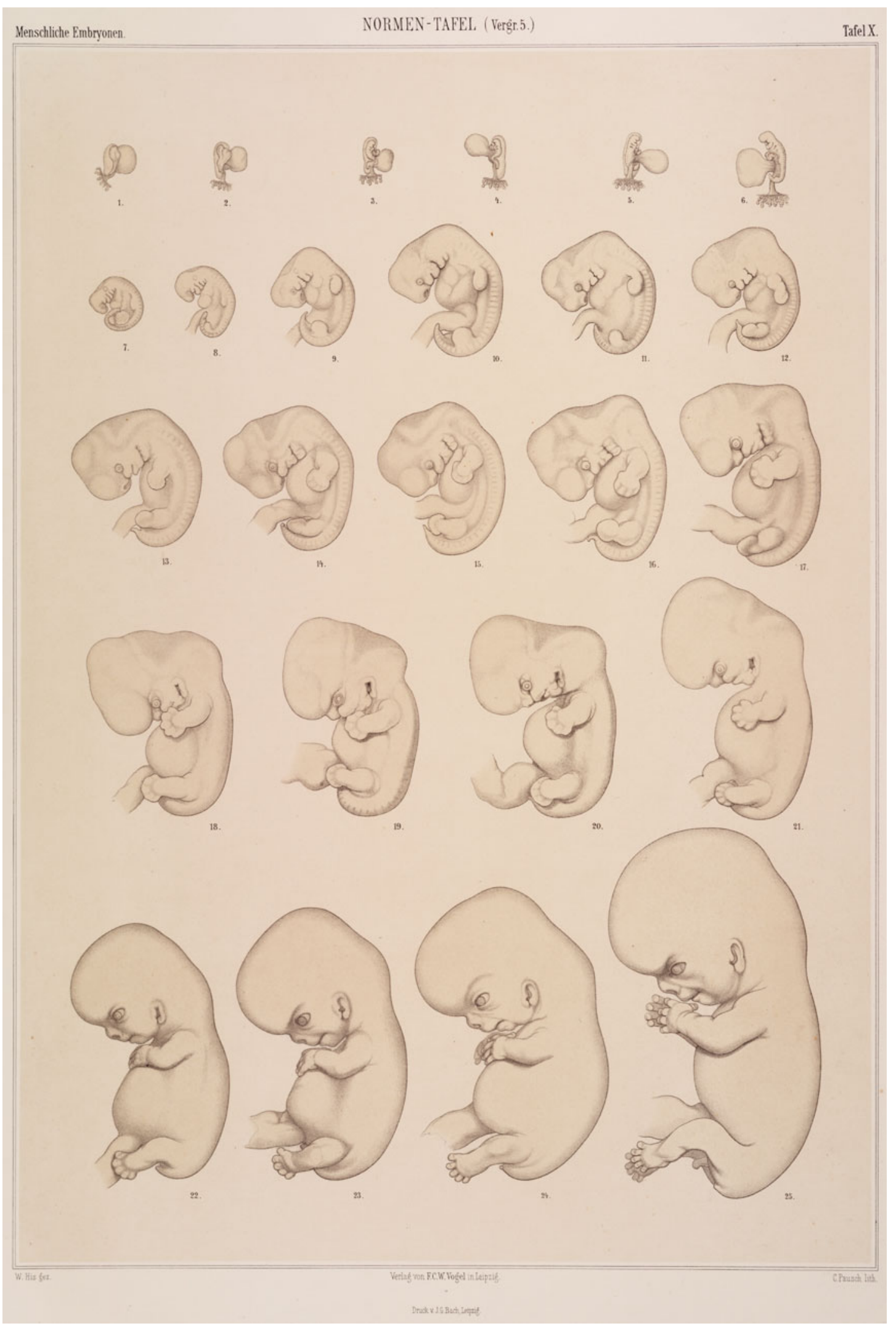

Fig. 5. Normentafel (normal plate) of human embryos. Lithograph by C. Pausch from His (1885), pl. X, by permission of the Syndics of Cambridge University Library. 


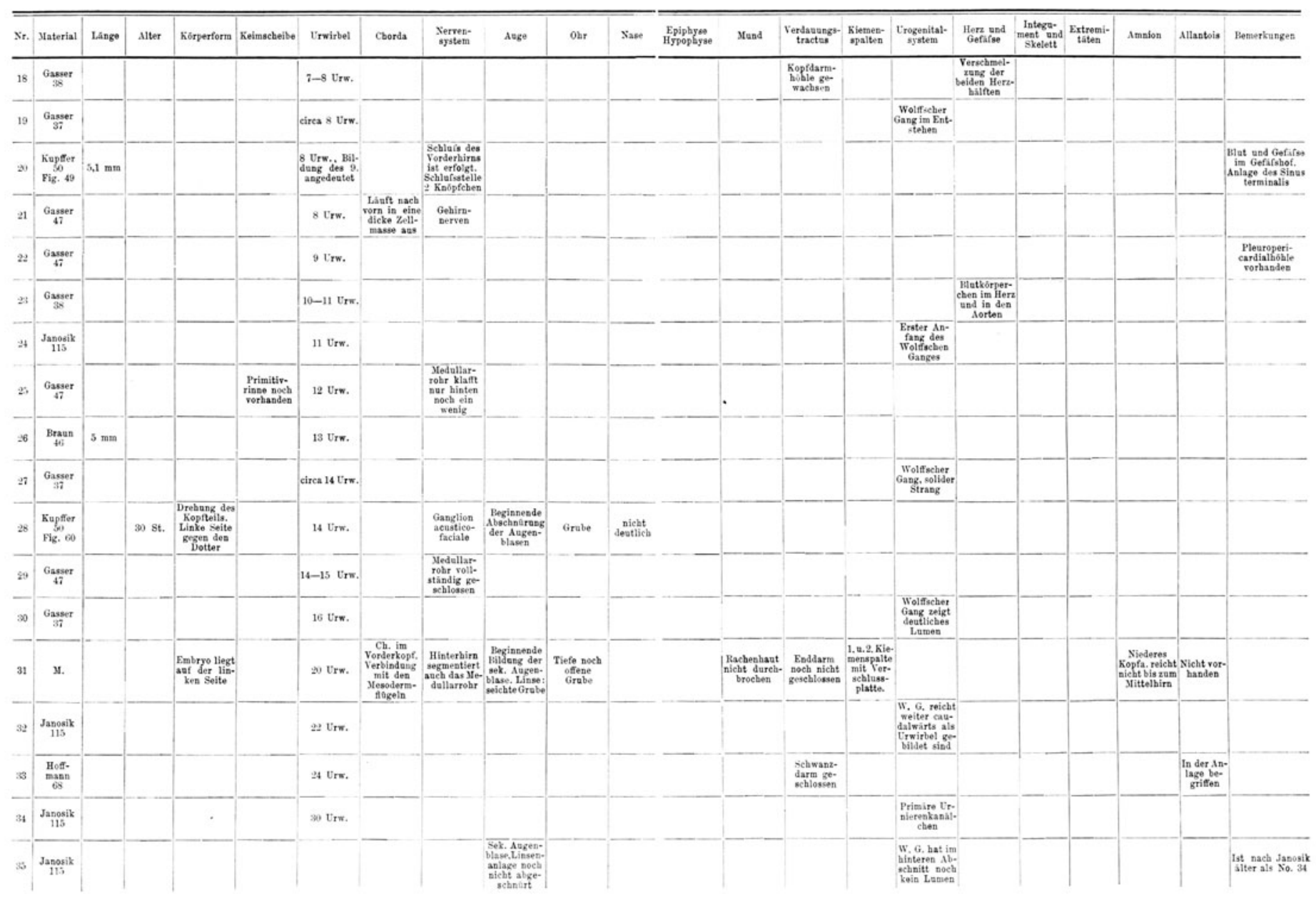

Fig. 6. Table of development by Albert Oppel. The rows represent specimens, the columns length, age, body form, germinal disc, somites, etc. This is part of one of several tables for the chick; Oppel had to use several because the authors described their material in incompatible ways, as either individual specimens (shown here) or stages. From Oppel (1891), pp. 132-133.

identified only from knowledge of animals' completed, active states. By the 1890s bitter and inconclusive turf wars were driving young scientists away from evolutionary morphology altogether (Nyhart, 1995, pp. 243-277).

Embryology was in turmoil. The most successful new approach was the German anatomist Wilhelm Roux's 'developmental mechanics', which went beyond His's modelling to investigate development experimentally (Maienschein, 1994; Nyhart, 1995, pp. 243-361). But experimental embryology, though active earlier, did not achieve institutional dominance until around 1930. The institutes of anatomy and of zoology, in which Roux's followers only slowly gained a hold, continued to recruit non-experimenting embryologists and, though thrown onto the defensive, 'descriptive embryology' was revived by new and demanding techniques. Pressure was strong on the anatomists, especially, to study the then experimentally inaccessible mammalian embryos. His's authoritative work on human embryos showed how. The normal plate made it easy to assess the significance of new specimens and the models displayed unprecedentedly detailed and accurate internal views in three dimensions (Hopwood, 2000, pp. 70-76; 2002).

Embryology gained enormously from Darwinism, but was still weakly, or at least diversely, institutionalized and riven by competing approaches. The problem, as His presented it, was only in part the rival programmes. It was also that the new descriptive methods made mastering development so time-consuming that individual investigators could tackle specific problems only. The result was a bewildering wealth of detail that led to "increasing fragmentation and confusion" (His, 1886, p. 554). The situation was especially troubling for younger anatomists who accepted the new techniques and saw the troubled relations between ontogeny and phylogeny as the major challenge in the field.

In 1891 a systematic test of the biogenetic law showed how much remained to be done. The Munich histologist Albert Oppel (Roux, 1917), recently moved to Freiburg in Baden, compared the degrees of development of organs at different times in different vertebrates. He criticized the easy-going practices that prevented him from using most of the embryological literature. Some authors gave age or length as though these had any general significance. Many set up stages on the basis of whatever organ they happened to be studying and aggregated features observed in different embryos into stages. But variations in the degree of development of different organs within species made arbitrary staging unreliable and the addition of new material difficult. Effective compari- 


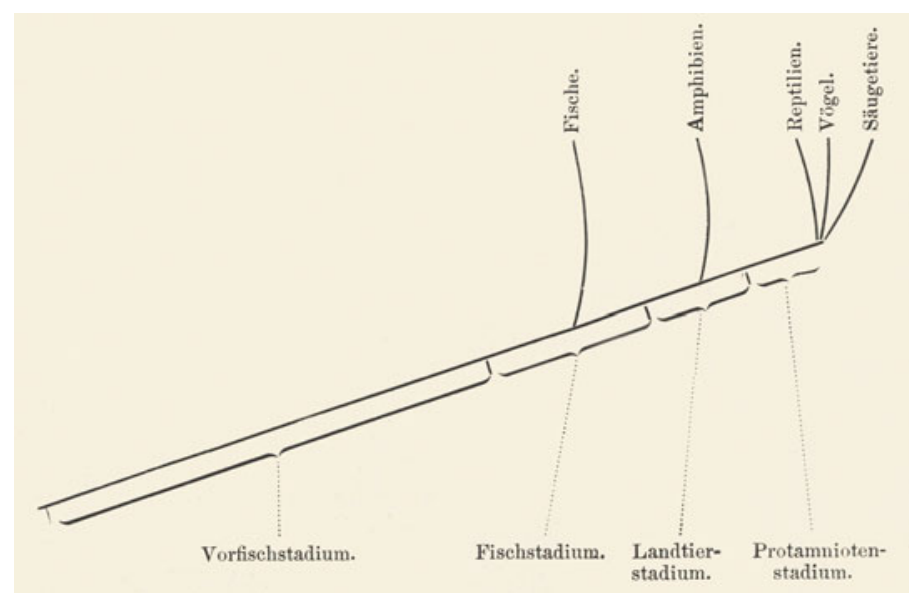

Fig. 7. Albert Oppel's similar ontogenetic stages in the development of a mammal or bird (prefish-, fish-, etc.) and the relation to them of the extant vertebrates (fishes, amphibians, etc.). Schema from Oppel (1891), p. 53.

sons needed systematic descriptions of the development of many organs within a series of individual embryos. Oppel provided a format for presenting internal analyses that could easily be compared and extended: a series of tables, at least one for each species, in which the columns represented dimensions and organs and the rows the progress of development (Fig. 6). Each row ideally corresponded to an individual specimen, but where this was impossible, he listed stages (Oppel, 1891). Though Oppel initially set up "similar ontogenetic stages" across the vertebrates, from "pre-fish", "fish" and "land animal" to "protoamniote" (Fig. 7), he soon abandoned the biogenetic law (Oppel, 1892, pp. 683-686). For Oppel and those who followed him, the crisis of comparative evolutionary embryology was a crisis of staging, not just between species, but also within them.

His proposed that embryologists should master such problems by establishing central institutions. The model was in part the Naples Station, which had provided embryological researchers from around the world with benchspace and organisms. The goal was to collect and prepare specimens, and produce drawings, photographs and models, and so to expand the common empirical ground on which embryologists of all persuasions could meet
(His, 1886, pp. 549-554). Several initiatives of the 1890s and early 1900s go back to His's proposal and use resources he produced. The first successful venture was the normal plates project of Oppel's Freiburg colleague, Franz Keibel.

Keibel would also reject the biogenetic law, but remained committed to the larger project of comparative evolutionary embryology. He insisted that embryologists could still extract phylogenetic information from ontogeny, if, rather than being put off by the temporal displacements, they studied them; and if, rather than relying on the literature, they carried out more thorough research with the new techniques. This was the primary aim of his Normal Plates of the Development of the Vertebrates, which drew on three of the innovations in presenting developmental series just reviewed. On the one hand, Haeckel's comparative plates served as an inspiration and a warning, flawed Darwinist icons that Keibel aimed to supersede. On the other, His's Normentafe/and Oppel's tables provided resources for comparative works that would respect the differences between species and even individuals.

\section{Normal plates between local critiques and interna- tional collaboration}

Keibel had a specific agenda, to provide more complete descriptions in order to reinvestigate the relations of ontogeny and phylogeny. He also had to respond to a set of locally intense comparative anatomical and anthropological critiques of embryology. But the desire for what His had shown were useful laboratory tools was shared widely enough for the project to gain international support.

Keibel (Fig. 8A) studied medicine in Berlin and at the Imperial University of Strasbourg in occupied Alsace, where in 1887 the anatomist-anthropologist Gustav Schwalbe supervised a craniological dissertation. After three years as Schwalbe's assistant, in 1889 Keibel was appointed prosector at the nearby University of Freiburg (Peter, 1929; Nauck, 1937) (Fig. 8B). His research, now all in embryology, was shaped by pressures peculiar to the anatomical institutes of the German south-west. While medical faculties generally hesitated to appoint comparative anatomists, whose claims to expertise in preparing physicians and surgeons were weak, Gegenbaur and his successor Max Fürbringer at Heidelberg and Robert Wiedersheim at Freiburg
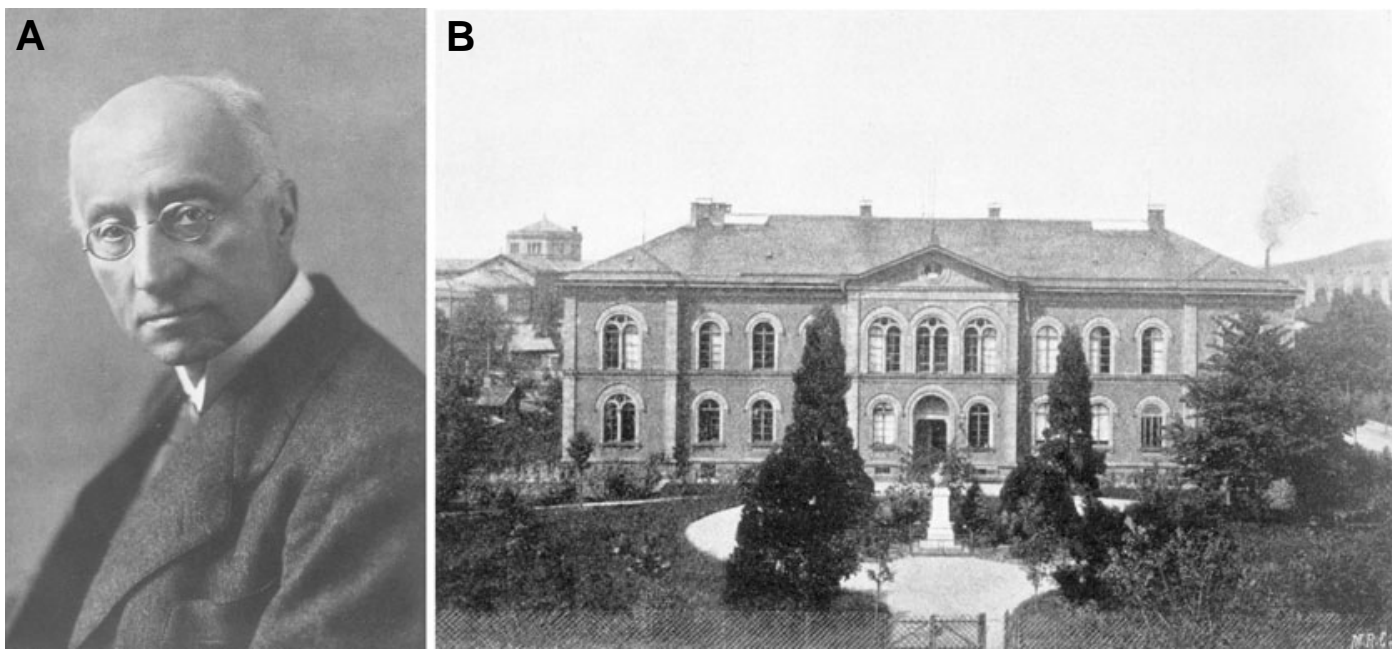

Fig. 8. Franz Keibel and the Freiburg anatomical institute. (A) Portrait photograph of the German anatomist Franz Keibel (1861-1929), editor of the Normal Plates of the Development of the Vertebrates. From Stieve (1929) by permission of the Syndics of Cambridge University Library. (B) The Freiburg anatomical institute around 1900. The bust in the front garden is of Alexander Ecker, who had it built in 1857. Photograph from Badischer Architecten- und Ingenieur-Verein (1898), p. 504. 


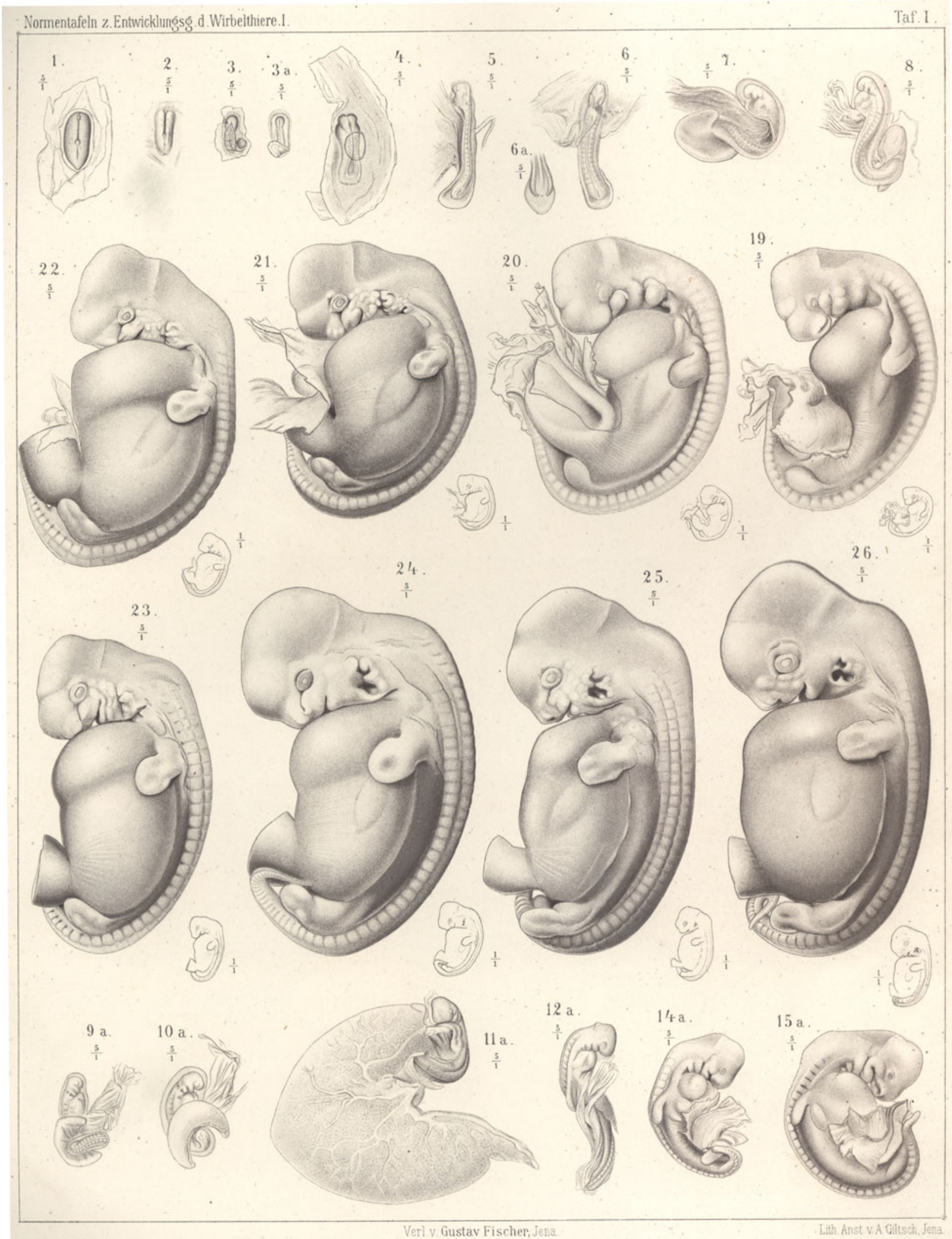

Fig. 9. Normal plate of the development of the pig from Franz Keibel's own first volume in his series of normal plates. Lithograph by Adolf Giltsch from Keibel (1897), pl. I. Original dimensions of border $26.3 \times 20.4 \mathrm{~cm}$. 
ran two of the anatomical institutes most dedicated to comparative research (Nyhart, 1995, pp. 207-240; Hopwood, 2002, pp. 57-67). While most anatomists did some anthropology on the side, Schwalbe led the way in bringing investigations of variation into the dissecting room (Keibel, 1916). So in this anatomical community comparative studies were looked on kindly, but adult anatomy and anthropology were dominant. Keibel had to engage with sharp criticisms of embryology that circulated in the Gegenbaur school and among Schwalbe's colleagues.

This is evident in Keibel's first major investigation, of pig embryos, in which he argued that embryologists could not trace the development of adult structures from the germ, or draw phylogenetic conclusions, as easily as they had thought. Since up-to-date methods, especially of sectioning and modelling, had been applied only to particular periods and/or individual organs, embryologists lacked "a single really complete embryology" of any vertebrate. It was time to go back to detailed studies of individual species, which should proceed backwards to the more obscure earlier conditions. This had always been done in human embryology, and Keibel had fewer pig than His had had human embryos, but embryology had usually been presented as allowing a morphologist to follow development from the simple to the complex. That had also been the justification for studying supposedly primitive species, but Keibel defended the relevance to human beings and the intrinsic evolutionary interest of mammals (Keibel, 1893, pp. 1-10).

Keibel presented his study as a test of the biogenetic law.
Unable to fit tables he constructed for the pig into Oppel's stages, he concluded that the temporal "jumblings up" (Durcheinanderschiebungen)_-displacements" was too mild a term-were such that, for mammals at least, the law was false. One could not distinguish a fish, let alone a generalized landanimal stage. "Temporal separation is inherent in the concept of stage", Keibel argued, "and to me at least it appears impossible to speak of stages temporally displaced through or over one another" (Keibel, 1895a, pp. 17-18, 75-78). The embryological evidence of evolution was more complex, but-against Gegenbaur's claim that adult anatomy should always be the final court of appeal-could be unlocked by making those troublesome temporal displacements the topic of research (Keibel, 1898, pp. 731-736). Keibel also proposed that studies of the developmental relations of different organs in particular species and of particular organs across species would reveal physiologically important interactions. In this way, comparative and experimental approaches converged on the problem of 'correlation', the interdependence of parts in ontogeny and in phylogeny (Keibel, 1893, p. 5).

Normal Plates of the Development of the Vertebrates aimed to provide embryology with a strong foundation from which to contribute to evolutionary studies from a position of strength. In October 1895 Keibel called for collaborators (Keibel, 1895b). By February 1896 the anatomists' house publisher, Gustav Fischer of Jena, had agreed to bring out the plates (Keibel, 1896). Keibel needed help-no lone embryologist could have studied enough vertebrates in the detail now demanded-and since many librar-

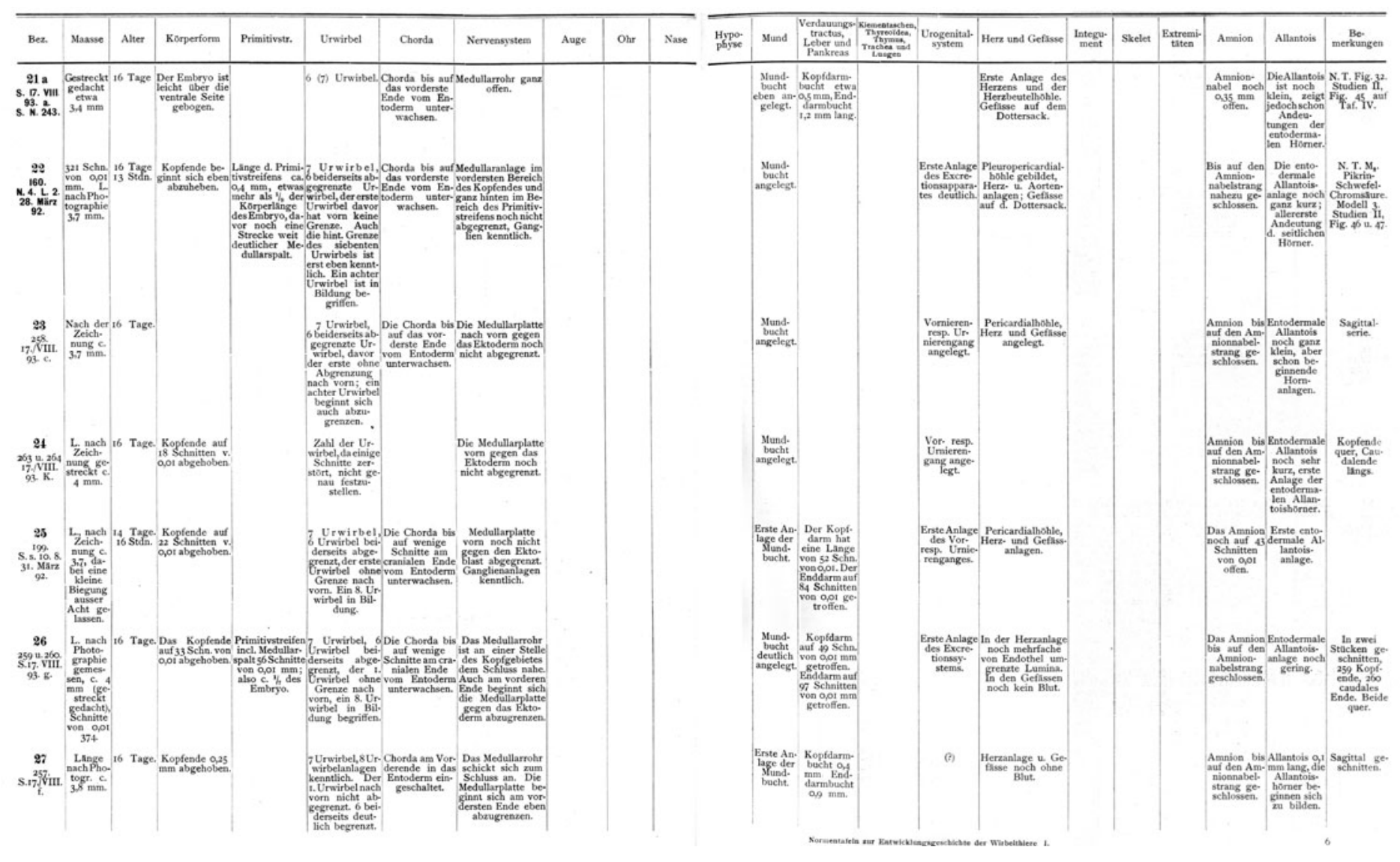

Fig. 10. Table of pig development. From Keibel (1897), pp. 40-41. Original width $20.5 \mathrm{~cm}$ on each of the two pages. 

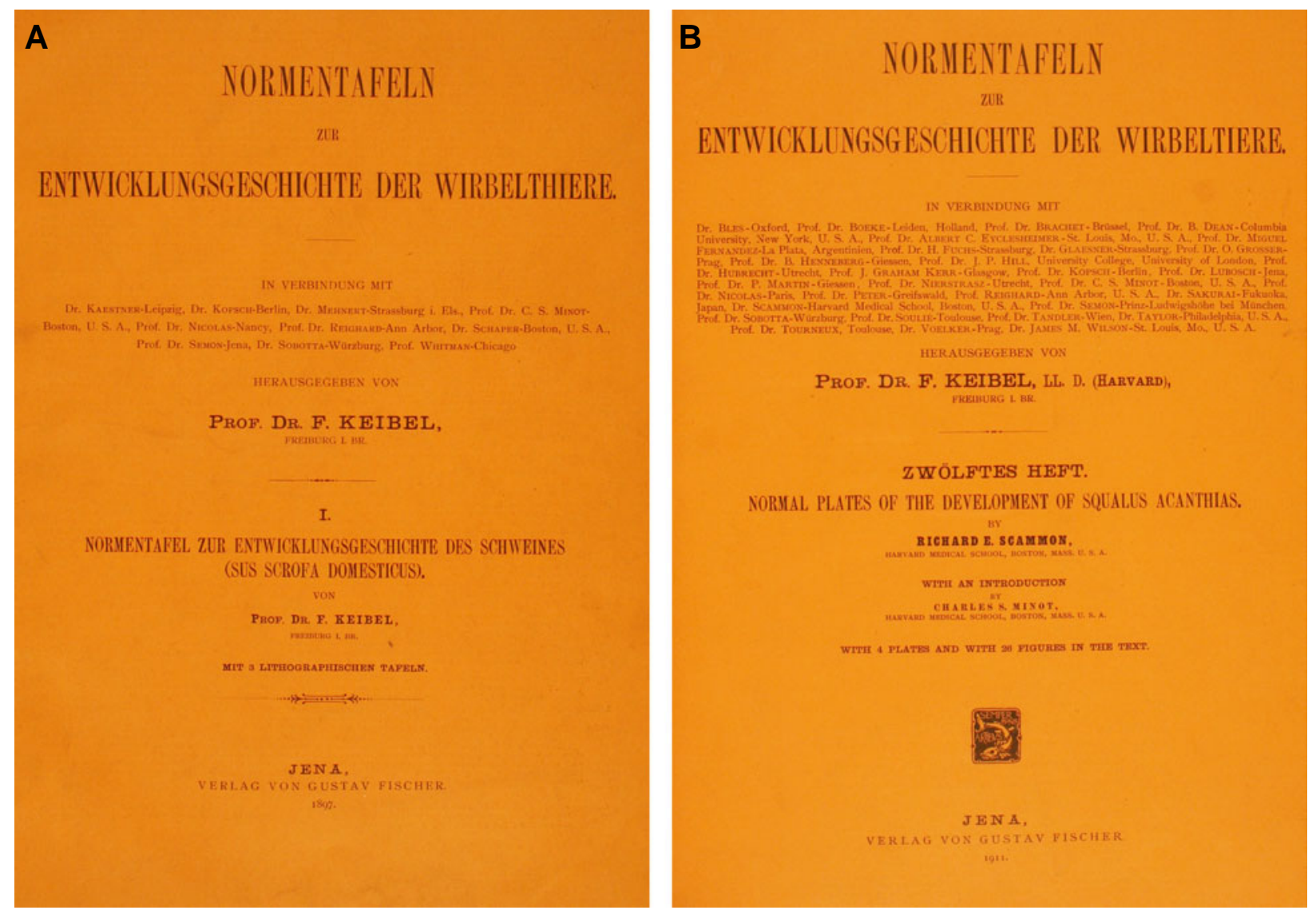

Fig. 11. Covers of Keibel's Normal Plates of the Development of the Vertebrates, with collaborators' names. Compared to (A) volume 1 on the pig (Keibel, 1897), (B) volume 12 on the dogfish (Scammon, 1911) shows the recruitment of many more authors than had by this point withdrawn (see Table 1). Keibel had also gained a Harvard doctorate of laws. Publication was in English when this was the author's preferred language.

ies would buy all of a series, this was economically more attractive than individual volumes. But the plates were specialist works with print runs of only $300 .^{1}$

We can see Keibel as taking each column of Haeckel's famous-notorious comparative plates and turning it into a complex monograph in which the various heterochronies that prevented specialists from simply lining up embryos at particular stages could be explored. Keibel established a new genre by combining plates (Tafeln) modelled on His's and tables (Tabellen) that modified Oppel's design. The first issue-which re-published Keibel's work on the pig-set the pattern for quarto volumes of plates, tables and text (Keibel, 1897). The text was little more than legends to the plates plus a substantial bibliography. Two plates illustrated the external morphology of individual embryos selected to form a continuous series up to the completion of the external organization (Fig. 9). The third gave more highly magnified images of the earliest stages, though cleavage and gastrulation were to be shown, if at all, only in enough detail to indicate the type of development. The tables complemented the plates by describing internal structures. Based on serial sections, they indicated the degree of development of the overall body form, the primitive

Note 1: Annelise von Lucius (Gustav Fischer Verlag) to Friedrich Kopsch, 26 May 1952, Thüringisches Hauptstaatsarchiv Weimar: Archiv Verlagshaus Gustav Fischer Jena, Korrespondenzakte 1952, KI-Lat. streak, somites, notochord, nervous system and so on (Fig. 10).

In contrast to the selective plates, Keibel intended the tables to include many individuals. For His in 1872, "the variability of the structure of our body", was still only "an obstacle" to "the pictorial determination of absolute norms" (His, 1872, p. 9). By the 1890s, even embryology, which tends to be seen as a bastion of essentialism, participated in a movement to investigate normal variation. Naturalists' engagements with Darwinism were an important inspiration, but a by no means overwhelmingly Darwinist anthropology is the more immediate source (Schwalbe, 1898). By the early 1890 s, Schwalbe was turning the dissecting-room routine into an opportunity to explore variations throughout the adult body. Keibel came under pressure when Ernst Mehnert, who joined Schwalbe as an assistant in 1890 (Schwalbe, 1903), spearheaded a moral campaign against casual pronouncements of embryological norms.

Mehnert sharpened Oppel's critique of staging. Impressed by variations in bird and turtle embryos, Mehnert combed the literature for more. He railed against the assumption "that embryos of the same species belonging to the same stage are completely the same as each other and that as a result more or less any embryo may serve as norm for the relevant stage of the species investigated". "Mostly one embryo, one series is singled out-which the author in question happens to find typical-and described exactly. The correlation of the organs found in this object is desig- 
TABLE 1

SERIES OF NORMAL PLATES OF THE DEVELOPMENT OF THE VERTEBRATES

\begin{tabular}{|c|c|c|c|c|c|c|c|c|}
\hline \multirow[b]{2}{*}{ Number } & \multicolumn{2}{|c|}{ Date } & \multicolumn{4}{|c|}{ Author } & \multicolumn{2}{|c|}{ Species } \\
\hline & $\begin{array}{l}\text { Published } \\
\text { or withdrawn }\end{array}$ & $\overline{\text { Agreed }}$ & Name & Dates & Location & Discipline & Latin name & Common name \\
\hline \multicolumn{9}{|c|}{ Franz Keibel's Normal Plates of the Development of the Vertebrates (Jena: Fischer) } \\
\hline 1 & 1897 & & Franz Keibel & $1861-1929$ & Freiburg & Anatomy & Sus scrofa domesticus & Pig \\
\hline 2 & 1900 & & $\begin{array}{l}\text { Franz Keibel } \\
\text { Karl Abraham }\end{array}$ & $\begin{array}{l}1861-1929 \\
1877-1925\end{array}$ & $\begin{array}{l}\text { Freiburg } \\
\text { Freiburg }\end{array}$ & $\begin{array}{l}\text { Anatomy } \\
\text { Med. student }\end{array}$ & Gallus domesticus & Fowl \\
\hline 3 & 1901 & 1897 & Richard Semon & $1859-1918$ & near Munich & Phylogeny & Ceratodus forsteri & Australian lungfish \\
\hline 4 & 1904 & 1900 & Karl Peter & $1870-1955$ & Breslau & Anatomy & Lacerta agilis & Sand lizard \\
\hline 5 & 1905 & $\begin{array}{l}1896 \\
1903\end{array}$ & $\begin{array}{l}\text { Charles S. Minot } \\
\text { Ewing Taylor }\end{array}$ & $\begin{array}{l}1852-1914 \\
1874-1971\end{array}$ & $\begin{array}{l}\text { Harvard } \\
\text { Harvard }\end{array}$ & $\begin{array}{l}\text { Anatomy } \\
\text { Histol., emb. }\end{array}$ & Lepus caniculus & Rabbit \\
\hline 6 & 1906 & 1905 & $\begin{array}{l}\text { Tsunejiro Sakurai } \\
\text { (Franz Keibel) }\end{array}$ & $\begin{array}{l}1872-1928 \\
1861-1929\end{array}$ & $\begin{array}{l}\text { Freiburg } \\
\text { Freiburg }\end{array}$ & $\begin{array}{l}\text { Anatomy } \\
\text { Anatomy }\end{array}$ & Cervus capreolus & Roe deer \\
\hline 7 & 1907 & 1905 & $\begin{array}{l}\text { A.A.W. Hubrecht } \\
\text { Franz Keibel }\end{array}$ & $\begin{array}{l}1853-1915 \\
1861-1929\end{array}$ & $\begin{array}{l}\text { Utrecht } \\
\text { Freiburg }\end{array}$ & $\begin{array}{l}\text { Zoology } \\
\text { Anatomy }\end{array}$ & $\begin{array}{l}\text { Nycticebus tardigradus } \\
\text { Tarsius spectrum }\end{array}$ & $\begin{array}{l}\text { Slender loris } \\
\text { Spectral tarsier }\end{array}$ \\
\hline 8 & 1908 & & $\begin{array}{l}\text { Franz Keibel } \\
\text { Curt Elze } \\
\text { (Ivar Broman) } \\
\text { (J. August Hammar) } \\
\text { (Julius Tandler) }\end{array}$ & $\begin{array}{l}1861-1929 \\
1885-1972 \\
1868-1946 \\
1861-1946 \\
1869-1936\end{array}$ & $\begin{array}{l}\text { Freiburg } \\
\text { Freiburg } \\
\text { Lund } \\
\text { Uppsala } \\
\text { Vienna }\end{array}$ & $\begin{array}{l}\text { Anatomy } \\
\text { Med. student } \\
\text { Anatomy } \\
\text { Anatomy } \\
\text { Anatomy }\end{array}$ & Homo sapiens & Human \\
\hline 9 & 1909 & $\begin{array}{l}1906 \\
1905\end{array}$ & $\begin{array}{l}\text { Otto Grosser } \\
\text { Julius Tandler }\end{array}$ & $\begin{array}{l}1873-1951 \\
1869-1936\end{array}$ & $\begin{array}{l}\text { Vienna } \\
\text { Vienna }\end{array}$ & $\begin{array}{l}\text { Anatomy } \\
\text { Anatomy }\end{array}$ & Vanellus cristatus & Lapwing \\
\hline 10 & 1909 & 1905 & $\begin{array}{l}\text { John Graham Kerr } \\
\text { (John S. Budgett) }\end{array}$ & $\begin{array}{l}1869-1957 \\
1872-1904\end{array}$ & $\begin{array}{l}\text { Glasgow } \\
\text { Cambridge }\end{array}$ & $\begin{array}{l}\text { Zoology } \\
\text { Zoology }\end{array}$ & $\begin{array}{l}\text { Lepidosiren paradoxa } \\
\text { Protopterus annectens }\end{array}$ & $\begin{array}{l}\text { S. Amer. lungfish } \\
\text { African lungfish }\end{array}$ \\
\hline 11 & 1910 & $\begin{array}{l}1910 \\
1910 \\
1897\end{array}$ & $\begin{array}{l}\text { Albert C. Eycleshymer } \\
\text { James M. Wilson } \\
\text { (Charles O. Whitman) }\end{array}$ & $\begin{array}{l}1867-1925 \\
1842-1910\end{array}$ & $\begin{array}{l}\text { St. Louis } \\
\text { St. Louis } \\
\text { Chicago }\end{array}$ & $\begin{array}{l}\text { Anatomy } \\
\text { Anatomy } \\
\text { Zoology }\end{array}$ & Necturus maculosus & Mudpuppy \\
\hline 12 & $\begin{array}{l}1911 \\
1900\end{array}$ & $\begin{array}{l}1907 \\
1896 \\
1896\end{array}$ & $\begin{array}{l}\text { Richard E. Scammon } \\
\text { (Charles S. Minot) } \\
\text { (Alfred Schaper) }\end{array}$ & $\begin{array}{l}1883-1952 \\
1852-1914 \\
1863-1905\end{array}$ & $\begin{array}{l}\text { Harvard } \\
\text { Harvard } \\
\text { Harvard }\end{array}$ & $\begin{array}{l}\text { Anatomy } \\
\text { Anatomy } \\
\text { Anatomy }\end{array}$ & Squalus acanthias & Spiny dogfish \\
\hline 13 & 1922 & 1905 & Otomar Völker & $1871-1955$ & Brno & Anatomy & Spermophilus citillus & Ground squirrel \\
\hline 14 & 1925 & 1909 & Leopold Glaesner & $1885-$ & Hildesheim & Zoology & Molge (Triturus) vulgaris & Smooth newt \\
\hline 15 & 1937 & 1901 & Bruno Henneberg & $1867-1941$ & Giessen & Anatomy & Rattus norvegicus & Brown rat \\
\hline 16 & 1938 & & Tokuyasu Kudô & $1888-1955$ & Niigata & Zoology & Megalobatrachus japonicus & Giant salamander \\
\hline \multicolumn{9}{|c|}{ Institut International d'Embryologie Monographs on the Normal Development of Vertebrates (Utrecht: Oosthoek) } \\
\hline 1 & $\begin{array}{l}1932 \\
1915\end{array}$ & $\begin{array}{l}1905 \\
1917 \\
1905\end{array}$ & $\begin{array}{l}\text { Hugo F. Nierstrasz } \\
\text { Daniel de Lange } \\
\text { (A.A.W. Hubrecht) }\end{array}$ & $\begin{array}{l}1872-1937 \\
1878-1947 \\
1853-1915\end{array}$ & $\begin{array}{l}\text { Utrecht } \\
\text { Utrecht } \\
\text { Utrecht }\end{array}$ & $\begin{array}{l}\text { Zoology } \\
\text { Zoology } \\
\text { Zoology }\end{array}$ & Tupaia javanica & Javan tree shrew \\
\hline 2 & 1937 & & $\begin{array}{l}\text { Fokko J. Huisman } \\
\text { Daniel de Lange }\end{array}$ & $\begin{array}{l}1898- \\
1878-1947\end{array}$ & $\begin{array}{l}\text { Utrecht } \\
\text { Utrecht }\end{array}$ & $\begin{array}{l}\text { Zoology } \\
\text { Zoology }\end{array}$ & Manis javanica & Malayan scaly anteater \\
\hline \multicolumn{9}{|c|}{ Agreed, but published after the series had ceased to appear } \\
\hline & 1952 & 1897 & Friedrich Kopsch & $1868-1955$ & Berlin & Anatomy & Rana fusca & Brown grass frog \\
\hline & 1969 & 1936 & Ross G. Harrison & $1870-1959$ & New Haven & Zoology & Amblystoma punctatum & Spotted salamander \\
\hline \multicolumn{9}{|c|}{ Agreed, but not published as separate works } \\
\hline & 1900 & 1897 & Sándor Kaestner & $1865-1924$ & Leipzig & Anatomy & & Chick, duck \\
\hline & & 1897 & Friedrich Kopsch & $1868-1955$ & Berlin & Anatomy & $\begin{array}{l}\text { Trout } \\
\text { Triton }\end{array}$ & Newt \\
\hline & 1900 & 1897 & Ernst Mehnert & $1864-1902$ & Strasbourg & Anatomy & $\begin{array}{l}\text { Emys lutaria taurica } \\
\text { Struthio africanus }\end{array}$ & $\begin{array}{l}\text { Turtle } \\
\text { Ostrich }\end{array}$ \\
\hline & 1922 & 1897 & Adolphe Nicolas & $1861-1939$ & Nancy & Anatomy & Anguis fragilis & Slow worm \\
\hline & 1922 & 1897 & Jacob Reighard & $1887-1942$ & Ann Arbor & Zoology & Amia & Bowfin \\
\hline & 1918 & 1897 & Richard Semon & $1859-1918$ & Jena & Phylogeny & & Monotremes \\
\hline & 1901 & 1897 & Johannes Sobotta & $1869-1945$ & Würzburg & Anatomy & Belone acus & Garfish \\
\hline & 1929 & 1900 & Franz Keibel & $1861-1929$ & Freiburg & Anatomy & & Duck \\
\hline & 1922 & 1900 & Wilhelm Lubosch & $1875-1938$ & Breslau & Anatomy & Petromyzon planeri & Lamprey \\
\hline & 1909 & 1900 & Kakichi Mitsukuri & $1857-1909$ & Tokyo & Zoology & Trionyx japonicus & Asian softshell turtle \\
\hline & 1906 & 1900 & Georg Wetzel & $1871-1951$ & Breslau & Anatomy & & An ophidian \\
\hline & 1904 & 1901 & Eugen Fischer & $1874-1967$ & Freiburg & Anatomy & & Mole \\
\hline & 1922 & 1901 & Paul Martin & $1861-1937$ & Zürich & Vet. anat. & & Cat \\
\hline & 1922 & 1901 & Johannes Sobotta & $1869-1945$ & Würzburg & Anatomy & Syngnathus & Pipefish \\
\hline & 1928 & 1904 & Bashford Dean & $1867-1928$ & New York & Zoology & & \\
\hline & 1921 & 1904 & Albert H. Soulié & $1867-1921$ & Toulouse & Anatomy & & \\
\hline & 1922 & 1904 & Frédéric Tourneux & $1852-1922$ & Toulouse & Histology & & \\
\hline & & 1905 & Edward J. Bles & $1864-1926$ & Glasgow & Zoology & & \\
\hline & & 1905 & Jan Boeke & $1874-1956$ & Helder & Anatomy & & \\
\hline & 1922 & 1906 & Albert Brachet & $1869-1930$ & Brussels & Anatomy & & \\
\hline & 1922 & 1906 & Thilo Krumbach & $1874-1949$ & Breslau & Zoology & & \\
\hline & 1909 & 1907 & Alfred Greil & $1876-1964$ & Innsbruck & Anatomy & & \\
\hline & 1922 & 1909 & Hugo Fuchs & $1875-1954$ & Strasbourg & Anatomy & & \\
\hline & & 1911 & Miguel Fernández & 1882/3-1950 & La Plata & Zoology, comp. anat. & & \\
\hline & & 1911 & James P. Hill & $1873-1954$ & London & Zoology & & \\
\hline
\end{tabular}

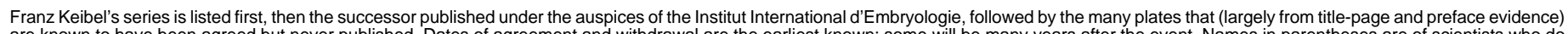

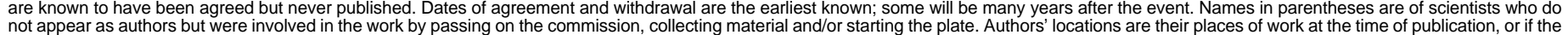
not appear as authors but were involved in the work by passing on the commission, collecting material and/or starting the plate. Authors' locations are their places of work at the
plate was not published, agreement. Species names are given, unmodernized, only when in the sources, except that a common name is provided for every Latin name listed. 
nated the 'norm' and the embryo in question registered as a 'stage'. These authors then also indicate exactly that this or that process begins at a certain number of somites." By contrast, embryologists who took the trouble to investigate many embryos found considerable variation. They avoided giving specific times for the appearance of a structure and speaking of 'stages'. They described the process of development within a certain period and took account of the individual deviations (Mehnert, 1895, p. 430).

Mehnert and Keibel had enough in common that Keibel presented a subsidiary purpose of the project as documenting individual variation and Mehnert signed up for plates on the turtle and the ostrich. But then they became embroiled in polemic and Mehnert pulled out before his early death in 1902. Gould discussed their disagreement over the biogenetic law (Gould, 1977, pp. 174-175), but variation was at least as important a bone of contention and the issues were linked. Mehnert found much more variation in Keibel's pig data than he would accept. While Keibel upheld the importance of correlation, Mehnert drew far-reaching evolutionary conclusions from the variations he took to signal the independent development of parts. But he insisted, absurdly in Keibel's view, that the biogenetic law was still valid-at the level of individual organs (Mehnert, 1897; 1898, pp. 331-332; 1899; Keibel, 1898, pp. 759-768; 1899; Keibel and Abraham, 1900, p. 13).

Schwalbe welcomed the Normentafe/nas laboratory tools, but, committed to statistical studies of variation and impressed by Mehnert's results, declared in a chairman's opening address to the German Anatomical Society that the statistical ideal of a Normentafe/would never be achieved (Schwalbe, 1898, p. 9). Keibel's defence highlighted their practical value and explained that the extraordinary numbers of embryos needed for significant results made this even harder than Schwalbe had realized (Keibel and Abraham, 1900, pp. 2-3, 13). He prevailed because few embryologists even had to consider the anthropological ideal of statistical norms.

More generally, Keibel could recruit to the project because, apart from investigating cenogeneses, a consensus formed on the desirability of the normal plates as laboratory tools. Even if the plates did not achieve the "highest and ultimate goals of embryology", each would at least provide "a good aid in embryological laboratories" (Keibel, 1898, p. 758), i.e., in ordering specimens in jars and on microscope slides and the corresponding drawings and models. Keibel sought to help authors over the great obstacles to describing thoroughly the development of a single species. The "subjective" difficulties were primarily that intellectual and career rewards accrued to those who focused on solving particular problems, whereas thoroughly describing the development of a single species involved tackling many problems simultaneously and postponing the decisive comparisons. The chief difficulty "in the object" itself, Keibel explained, was to obtain a complete series of specimens, something that was hard even for the chick but for mammals could be extremely costly and in some cases was practically impossible. By providing a framework for comparison, the series aimed to make the deceptively large amount of work a little more rewarding and significant (Keibel, 1895b). In practice, Keibel mostly signed up embryologists who already planned to study particular species; some researchers had special grants for the purpose. To reinforce the moral obligation he had their names printed on the title page and wrappers of
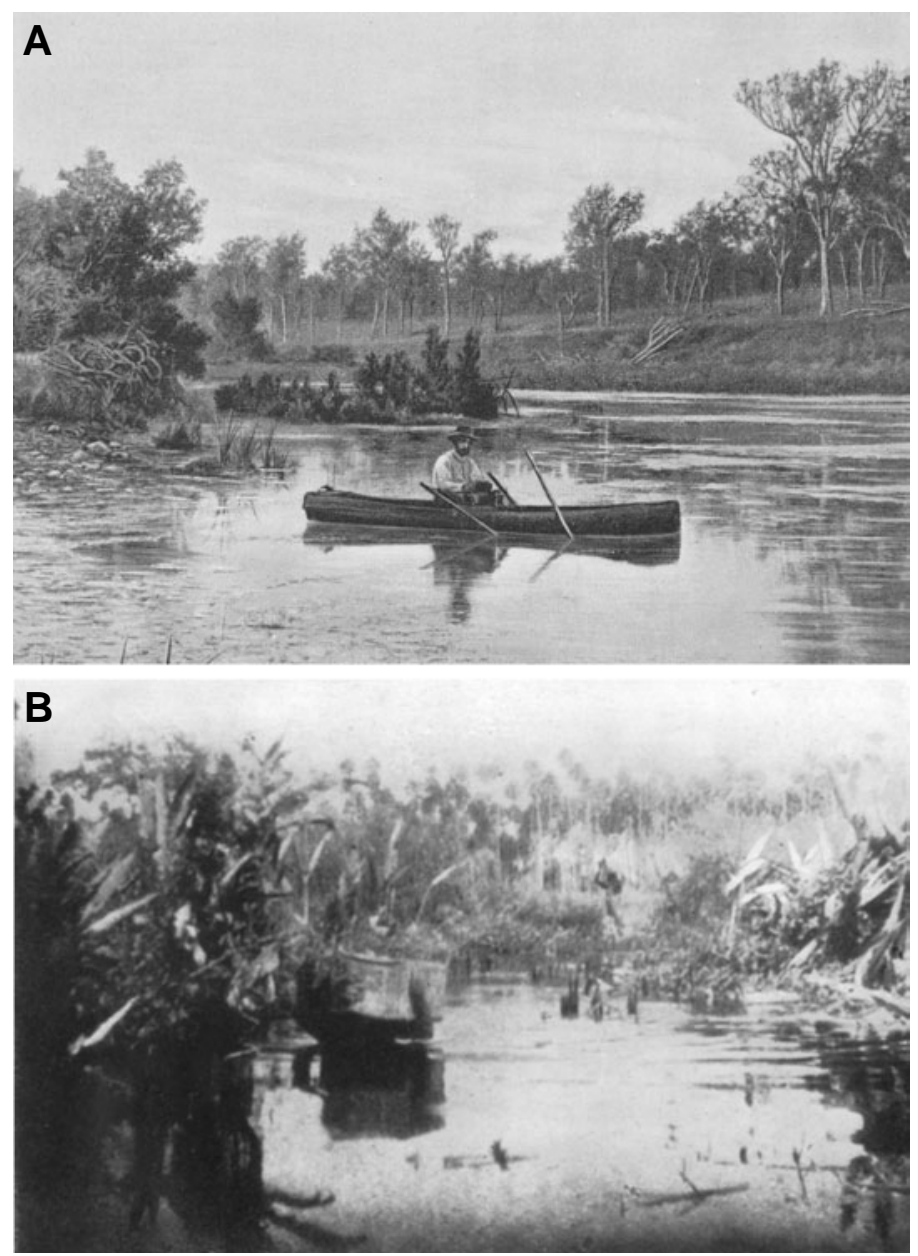

Fig. 12. Collecting lungfish embryos. (A) Richard Semon "[i]n search of Ceratodus spawn in the self-made canoe". (B) "Transport of one of [John Graham Kerr's] Lepidosiren packages through swamp stream". It is difficult to make out what is happening in (B), but unlike the illusion of the solitary explorer created in (A), it clearly involves a group. Photographs by permission of the Syndics of Cambridge University Library from (A) Semon (1896), facing p. 82; (B) Kerr (1950), pl. XXIIIb.

every volume-and removed as they pulled out or were prevented from participation (Fig. 11).

Table 1 lists the normal plates that appeared and more than as many again that were planned but did not. Keibel's team of over 40 anatomists and zoologists delivered 12 volumes covering 14 species before World War I temporarily halted the project. Recruitment is patterned by discipline, seniority and nationality. Within the German-speaking universities Keibel attracted only fellow anatomists; zoologists were more likely to study invertebrates. An associate professor, he recruited no German scientist more senior than himself. Keibel, his medical students and a Japanese visitor, plus the Freiburg-trained Karl Peter and the Austrians Otto Grosser and Julius Tandler, did most of the work. The United States made its most significant contribution through the German-trained embryologist Charles S. Minot, who was building up a collection at Harvard (Lewis, 1916), and Chicago zoologist Charles $\mathrm{O}$. Whitman. Both enlisted junior colleagues. The rest of the prewar plates were made by the zoological explorers, Haeckel's student Richard Semon, John Graham Kerr 


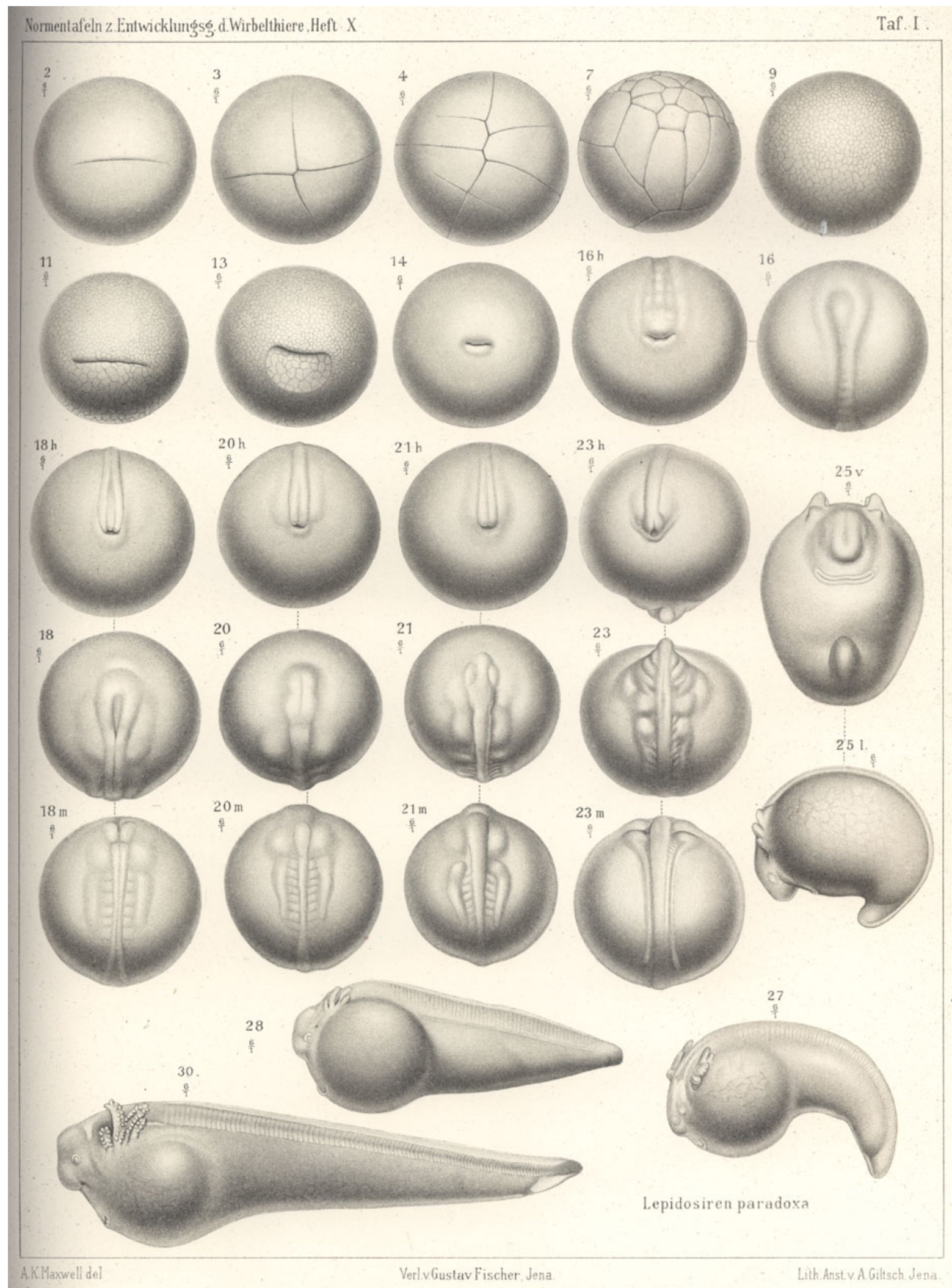

Fig. 13. Graham Kerr's normal plate of the development of the South American lungfish, Lepidosiren. By contrast with Fig. 9, which represents scarce mammalian embryos, the regular arrangement heightens the sense of confident mastery of the whole of early development. Lithograph by Adolf Giltsch after drawings by A. Kirkpatrick Maxwell from Kerr (1909), pl. I. Original dimensions of border $26.3 \times 20.0 \mathrm{~cm}$. 


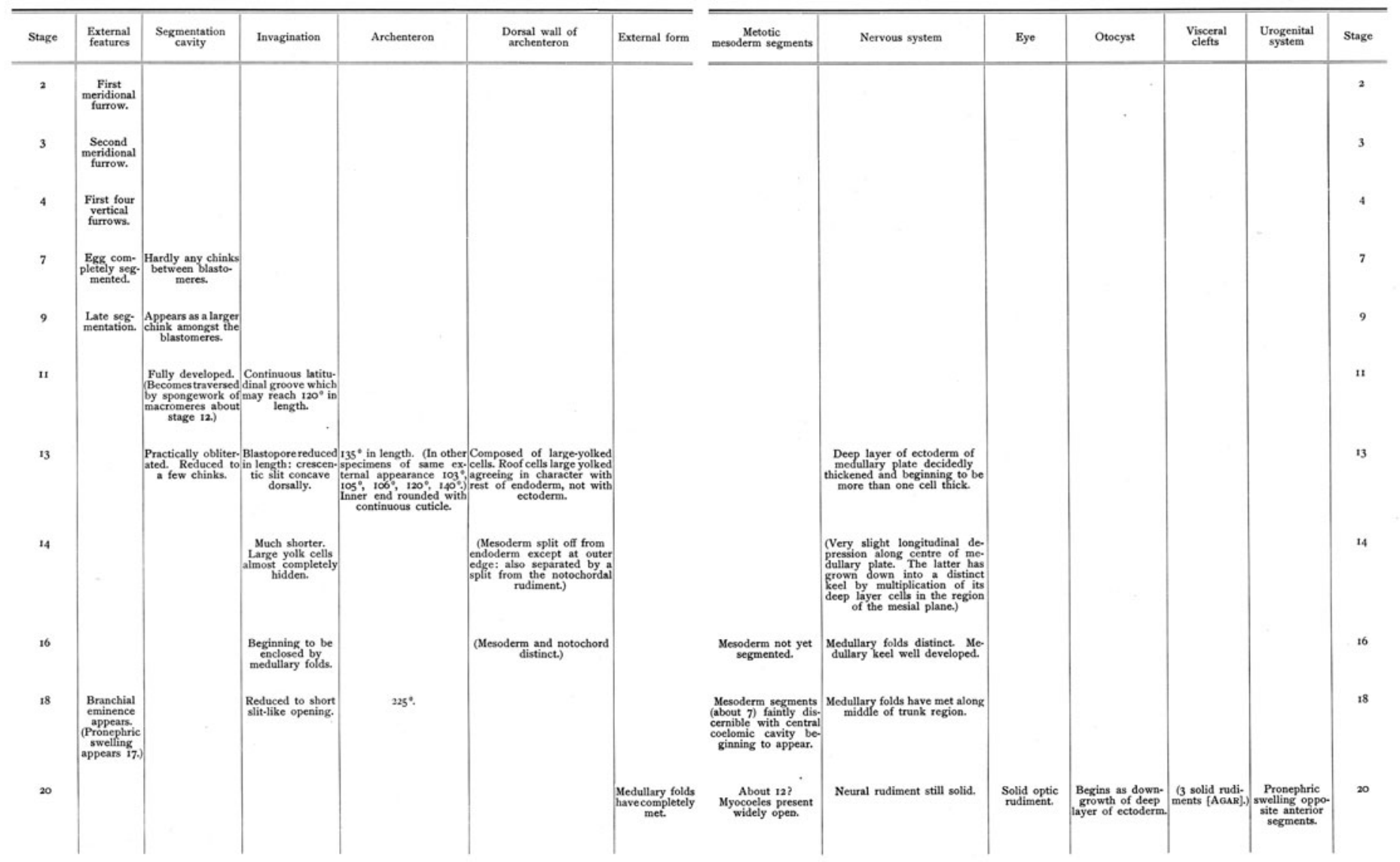

Fig. 14. Graham Kerr's table for Lepidosiren. Unlike Keibel's pig table (Fig. 10), which represents individual specimens, Kerr's shows stages. From Kerr (1909), pp. 12-13. Original width $18.7 \mathrm{~cm}$ on each of the two pages.

from the Cambridge school founded by Francis Balfour and A. A. W. Hubrecht of Utrecht. All had an interest in getting the most out of their hard-won material.

\section{An embryological empire in a publication series}

Keibel edited normal plates that describe the embryos of various vertebrates in a single standard series. His authors collected biologically, geographically and socially diverse objects and analysed them in a common framework, a precondition for comparative work. They mapped an embryological empire. The plates are different because embryologists could study some species much more freely than others and the difficulty of recruiting authors restricted Keibel's power to enforce a uniform approach. But all were at some level committed to a common project.

Keibel's authors joined forces to analyse species selected for their diverse systematic positions and because medicine, agriculture, hunting, fishing and tourism gave access to them. Embryologists had traditionally worked on humans when they could and the rise of operative gynaecology made earlier normal specimens available from the clinics (Clarke, 1987, pp. 332-334). No longer acceptable as surrogates, except for the earliest stages, but invaluable for comparison, were domestic amniotes that embryologists could breed or have bred themselves: chicks and (before the rise of the laboratory mouse) rabbits. More unusually, Peter raised lizards in terraria over several summers (Peter 1904, p. 2). Embryologists also cadged animals from farmers, hunters and fishermen or caught them in the wild. Keibel's landowning father gave him six pregnant pigs and Keibel himself went with local hunters to cut the uteri from the warm bodies of the does they killed (Keibel, 1893, pp. 10-11; Sakurai, 1906, preface). As a contrast to the chick Grosser and Tandler selected the lapwing because they expected its development to be unaffected by the "degenerative processes" that followed domestication and because it was available. Being developed for holidaymakers, the village of Fonyód on the south-eastern shore of Lake Balaton served as a base for collection from meadows adjoining the swamps (Grosser and Tandler, 1909, preface, pp. 1-2).

Intrepid embryologists used imperial networks to bring home 'living fossils' and 'missing links', ancient species with ranges outside Europe and the United States (MacLeod, 1994). These explorers were animated by a comparative ambition that now seems rapacious: "The jungles and hillsides of the world must be ransacked for out-of-the-way species which may fill the many gaps; embryos of squirrel and rabbit, sheep and dog must be set beside those of macaque and armadillo and of unheard-of creatures from distant lands like the tarsier [an arboreal and nocturnal primate of south-east Asia], tenrec [hedgehog-like Madagascan insectivores] and tupaia [south-east Asian tree-shrews]" (Corner, 1944, p. 28). Semon, Kerr and his companion John Samuel 

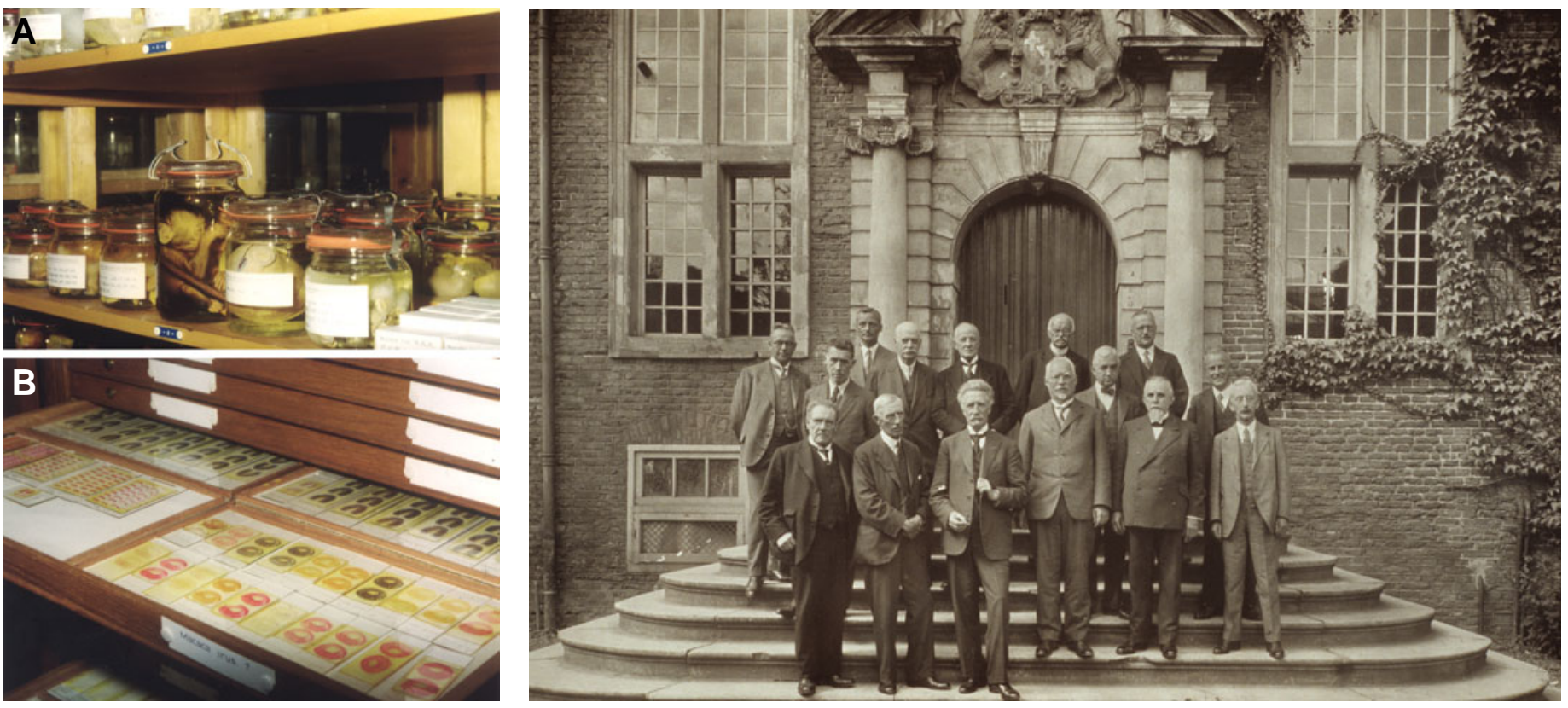

Fig. 15 (Left). The Hubrecht collection. (A) Whole embryos of the macaque monkey Macaca irus and (B) sections of the embryos on microscope slides in the Central Embryological Collection, when still at the Hubrecht Laboratory, Utrecht, Netherlands.

Fig. 16 (Right). Group portrait of the Institut International d'Embryologie in Utrecht, 4-5 September 1933. This was the fifth meeting, the second of four that were held between 1930 and 1938. Present were Th. Bryce, James P. Hill (London), Otto Grosser, Giuseppe Levi, Walther Vogt, J.F. Wilson, J.H. Woerdeman, Daniel de Lange, J. Boeke, Johan Frans van Bemmelen, Friedrich Kopsch, George L. Streeter (Baltimore), J.W. van Wijhe, L. Graeper and E.L. Goodrich. Photograph from Alan Mason Chesney Medical Archives, Johns Hopkins Medical Institutions, Baltimore: Carnegie Institution of Washington Department of Embryology Papers, record group 5, series 1, box 1, folder 18; names list on portrait at Hubrecht Laboratory.

Budgett went after lungfish on three continents because of their status as (relatives of the) links between fish and land animals. Semon travelled to Australia, while Kerr and Budgett fished the South American lungfish in the swamps of the Gran Chaco in Paraguay (Kerr, 1950) (Fig. 12). Budgett then independently collected the African lungfish on an island in the River Gambia and handed the embryos over to Kerr before dying as a result of an expedition to observe the development of another primitive fish (Kerr, 1901, p. 3; Hall, 2001). In Indonesia Hubrecht hunted prosimians as human ancestors (Hubrecht, 1894). The British Empire made Semon's trip possible and the South American Mission provided Kerr with transport, accommodation and contacts (Semon, 1896; Kerr, 1950, pp. 173-175).

Bringing specimens through these networks into their laboratories, Keibel's authors extended embryology's intellectual dominion by framing as embryos objects that their suppliers had often seen very differently. Closest to home, anatomists reinterpreted bleeds that had been experienced variously as unremarkable late periods, distressing miscarriages or desired restorations of menstrual flow and discovered embryos in the bodies of patients who had not even known they were pregnant (Hopwood, 2000, pp. 38-40). Kerr and Budgett first encountered the South American lungfish Lepidosirenwhen they came across "a party of Indians cooking their supper". Known as "the Paisiapto or black-food people", "their main food was a darkcoloured eel-like fish that abounded in the swamps by which they lived". Kerr ate "a plate of the cooked lungfish ... "con mucho gusto', for the flesh, rich with its deep orange red fat, was most tasty". Unlike the missionaries, he credited the Paisiapto "witch doctor", as "the common ancestor of our scientist, priest and physician", with "scientific knowledge of his environment" (Kerr, 1950, pp. 175, 179, 180-181). Budgett, by contrast, described the West African "natives" as "entirely ignorant of any but the most obvious facts of natural history", though the "head fisherman, Sory" had found him the first "children of the 'Cambona'" and so taught him where to look for the Protopterus nests (Budgett, 1901, p. 120). Prior interpretations were devalued as objects were endowed with enormous scientific worth, but Kerr could still see the embryologists' cult of missing links from the outside. He reported that his old Cambridge professor had been scandalized by the lungfish dinner, a "sacrilegious use of the sacred Lepidosiren" (Kerr, 1950, p. 179).

These extremely diverse specimens were all to be analysed and presented in the same way, but limitations on what could be collected-Hubrecht had only 10 loris embryos-combined with local styles of description to make the plates a series of variations on Keibel's theme. Microscopical and graphic procedures differed relatively little. Though he soon abandoned the plan to have a single artist re-draw everything, the embryos were generally shown in lithographs from the left or (for younger stages) the dorsal side at fivefold magnification (or multiples thereof) (Keibel, 1895, pp. 231, 233; 1896, p. 594). The original design was for the first two plates (Fig. 9) to display post-gastrulation development and the third to show supplementary pictures, especially of younger stages at higher magnification, but most authors preferred a single series across 
three or four plates. Embryos were sectioned and the results of internal analyses summarised in the tables (Fig. 10).

How were representatives selected and what did they represent? The Normentafe/project began with Keibel's inability to set up stages, or divisions based on general characters, that would be comparable across the mammals; it was informed by Oppel's and Mehnert's criticisms of naïve staging within species. Yet though Keibel and his direct collaborators avoided the term 'stage' and offered selections of mere individuals, the other authors made individual embryos characterize stages. Peter acknowledged that his figures showed "individuals and not 'stages"', but for the "purely practical purpose" of ordering a lizard embryo according to figure and description, "one can surely ... use that disreputable word 'stage'" (Peter, 1904, p. 3). All found stages and norms hard to standardize across species.

Authors differed also in the extent to which, where enough material was available, they approached variations assumed to be within the normal range. Keibel and Peter included many more embryos in the tables than the plates and commented on variations, but Kerr's tables describe only the lungfish specimens shown on the plates (Figs. 13-14). The Harvard embryologists, working on relatively abundant embryos, approached variation more systematically, but mainly in order to select the single best series for thorough analysis. Minot claimed for his rabbit embryos, for example, that he had largely determined "stages, which should be really nearly normal, i.e., representative of the median of the variations for each selected age", by selecting three individuals from the litter which for that age "appeared nearest central" (Minot and Taylor, 1905, p. 1).

Normal-plate makers had to deal especially carefully with any predecessors in the field. Should one extend a previous system or attempt to supplant it? For human embryos His's celebrated Normentafel provided a universally used and flexible framework. Keibel and Curt Elze managed both to pay homage, by dedicating the work to His's memory and including a version of the Normentafe/as the first figure and at the same time to stress its provisional character (Keibel and Elze, 1908, pp. iii, 6; Hopwood, 2000, pp. 74-76). In a field already choked with competing series, Scammon took another approach. Balfour's elasmobranch stages were so established that he had to relate his stages to them. So he reminded readers that Balfour's series mixed three species, fresh and fixed specimens and various unspecified magnifications and still contained major gaps. Scammon presented a "general correlation table" that subsumed this and nine other elasmobranch series within his own (Scammon, 1911, pp. 70-78).

In the different amounts of material Keibel's authors could collect and through the various ways they treated it, some biological, geographical and cultural distinctions were reproduced in the plates and tables. Yet the individual volumes did not need to be fully standardized for them to function as a series dedicated to a common project.

\section{Theoretical failure and institutional success}

Keibel's normal plates have a modest place in Gould's history of the "decline, fall and generalization" of Haeckel's biogenetic law (Gould, 1977, p. 174). In grand theoretical terms, the series did fail. Several authors identified heterochronies (e.g., Keibel and Elze, 1908, pp. 152-162), but no new synthesis emerged. Nor did the series lead to any general conclusion about variation. But as a practical and institutional success it had a lasting impact.

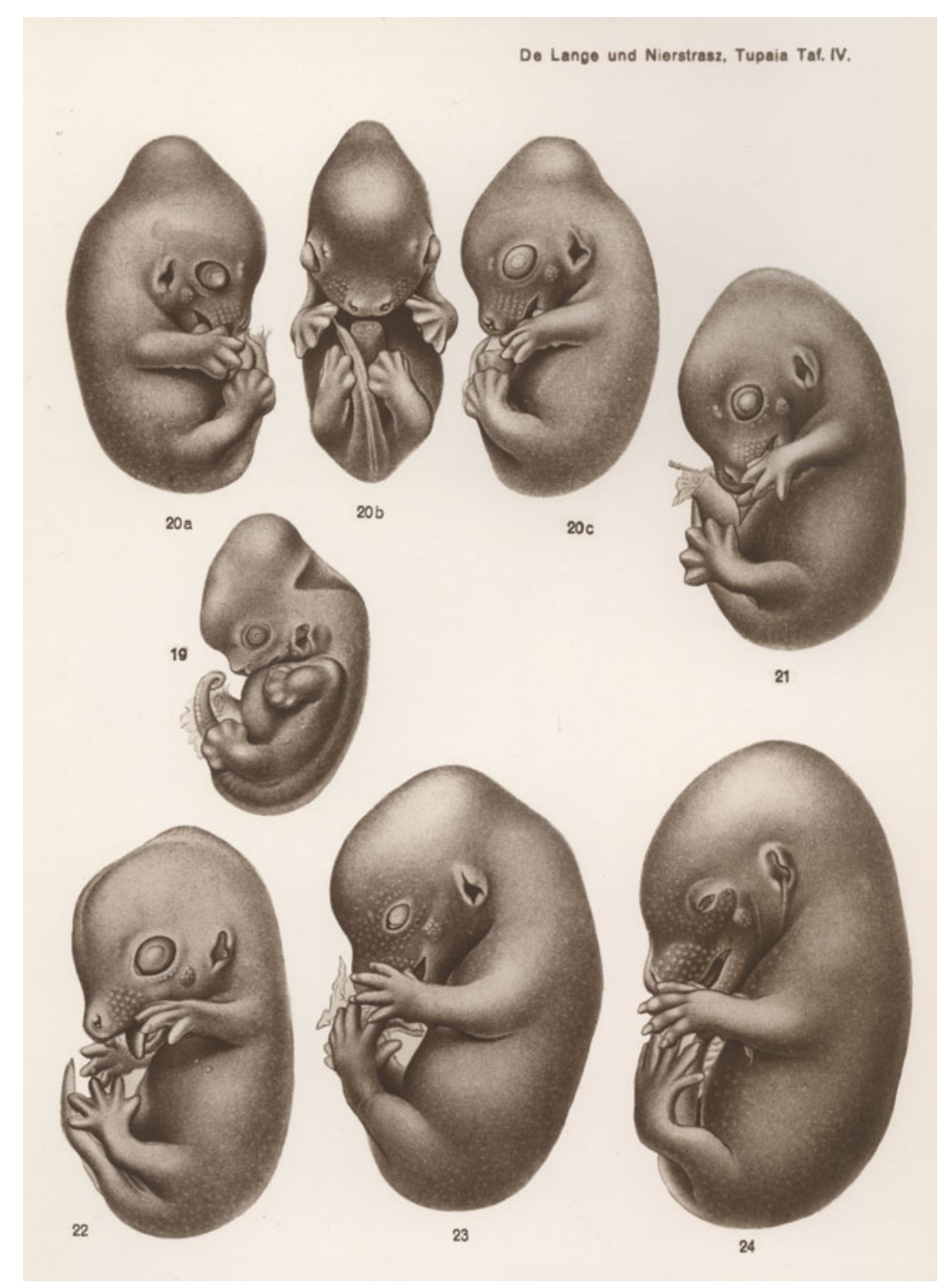

Fig. 17. Plate of Tupaia javanica embryos from the first of two Institut International d'Embryologie monographs on the normal development of the vertebrates. Members of the Institut were sent sample pictures and order forms. From de Lange and Nierstrasz (1932), pl. IV, by permission of the Syndics of Cambridge University Library. Original dimensions of plate $25.3 \times 18.8 \mathrm{~cm}$. 

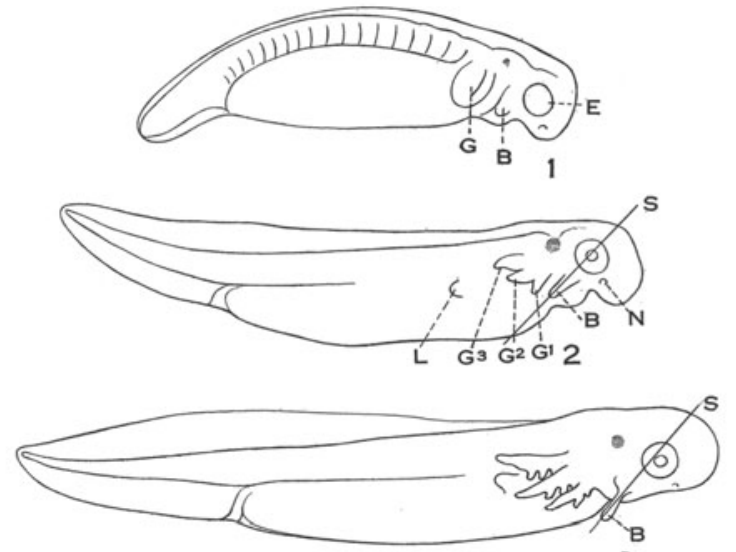

3

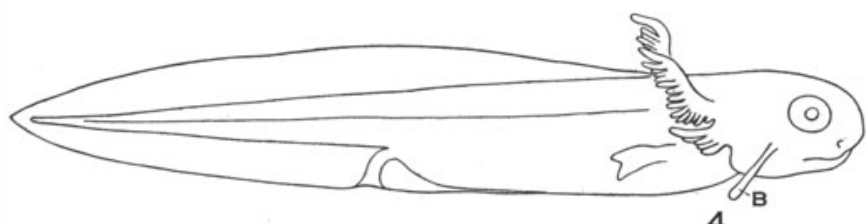

4

Figs. 1 to 4 Four normal stages of Amblystoma punetatum, showing the development of the balaneer. $B$, balancer; $G$, gills; $L$, anterior limb; $N$, nasal pit; $S$, line of section in figs. 50 to 55 , inclusive. $\times 8$.

Fig. 1 Stage 34 .

Fig. 2 Stage 37.

Fig. 3 Stage 39 .

Fig. 4 Stage 43 , showing the organ at the height of its development.

Fig. 18. Early pictures of selected normal stages from an article by Ross Harrison. Line drawings from Harrison (1925), p. 361.

In the nineteenth century there were very few chairs of embryology and embryologists met with anatomists and zoologists rather than among themselves. Only in the early twentieth century were separate embryological institutes and a specialist society created. Histories of biology lead us to expect that these would be the work of experimenting embryologists, but they made homes in biological institutes and marine stations. The new embryological institutions were founded by comparative and human embryologists who supported Keibel's project and for whom collecting and documenting sometimes became an end in itself.

Keibel worked with the American anatomist Franklin Paine Mall to establish human embryology in 1914 at a department funded by the Carnegie Institution of Washington in Baltimore. Devoted especially to the anatomy of human embryos, it became the leading institution in that field (O'Rahilly, 1988; Morgan, 2002; Noe, 2005). His failed to create a central embryological institution (His, 1901), but his plan led to the foundation in 1911 of the first specifically embryological society, the Institut International d'Embryologie (I.I.d'E.). At first an exclusive club of European comparative vertebrate embryologists, it promoted the collection of the embryos of endangered colonial mammals for central collections and normal plates (Nieuwkoop, 1961) (Fig. 15). After Hubrecht's death in 1915 an internationally oriented laboratory was established in his memory at Utrecht (Faasse, Faber and Narraway, 1999; Richardson and Narraway, 1999). Cooperation had started on Keibel's plates two decades before.

World War I ended the modest institutional revival of comparative embryology-work on human embryos continued apace- and halted the normal plates. Keibel, who had campaigned for German rearmament, endured a series of family tragedies and the confiscation of his scientific materials when the French reconquered Strasbourg. Even after 1922, when he gained a chair in Berlin, he could not pick up where he had left off (Peter, 1929, pp. 202-204). Many potential contributors had withdrawn or died and with access to material more restricted few offers came in. During these years of economic crisis Fischer struggled even to bring out those plates to which Keibel was already committed (Table 1). ${ }^{2}$

In 1930, a year after Keibel's death, Dutch embryologists led a rebirth of the Institut International (Fig. 16), opening the club to experimentalists and attempting to continue the normal plates. Fischer could not help, but wanted to keep the name. So Daniel de Lange and Hugo Nierstrasz negotiated a new series with a Utrecht publisher (de Lange and Nierstrasz, 1932, pp. 5-10). Two Monographs on the Normal Development of Vertebrates were produced under the auspices of the Institut (Fig. 17). For the third, Yale zoologist Ross Harrison (Maienschein, 1991, pp. 261-289) promised the spotted salamander Amblystoma punctatum, but it never appeared. In the late 1930s Fischer published two last Normentafeln in the old series, including long-delayed plates on the Norwegian rat, for which increasing laboratory use had created demand (Table 1).

Keibel's normal plates shared in the mid-twentieth-century marginalization of comparative embryology. With the organization in the last three decades of 'evolutionary developmental biology' they are again attracting interest. The most thorough available descriptions of several rare vertebrate embryos, they have, for example, provided resources to debate the notion of the phylotypic stage (e.g., Bininda-Emonds et al., 2002, pp. 301303). But just as making the normal plates wove a network through which embryology more generally would gain independence, so their uses were not bound to the mixed fortunes of comparative research. Suitably adapted, they also provided other fields with important tools.

\section{From normal plates to staging systems}

From about 1914 two groups of embryologists began to transform the Normentafe/ design. Though neither was much interested in evolution or variation, they were at opposite poles of the science and so offer a useful contrast. Experimentalists, now using sophisticated microsurgery to explant and transplant tissue within and between embryos of different species and degrees of development, sought convenient tools for rapid staging of living embryos, especially amphibia and the chick; 'normal' here meant development without experimental intervention. Human embryologists invented a system for ordering their detailed reconstructions of individual specimens.

Early-twentieth-century biologists were starting to concentrate on fewer species. Embryological experimenters, noticing the plates for lungfishes and the lapwing, soon felt their lack for the groups they used most. The first widely adopted 'normal stages' by an experimenting embryologist were Harrison's for the salamander, begun long before those negotiations with the I.I.d'E.

Note 2: Fischer to Keibel, 9 December 1922, Thüringisches Hauptstaatsarchiv Weimar: Archiv Verlagshaus Gustav Fischer Jena, Korrespondenzakten. 
Fig. 19. Photographs of Lisbeth Krause's wash-drawings representing Ross Harrison's normal stages of Amblystoma punctatum. The first picture on this first of seven sheets is of an unsegmented egg (stage 1), including the jelly, the last of an early blastula (stage 8). The drawings themselves mimicked the effect of photography, but allowed the artist more freedom to heighten definition. Harrison gave this set to his student William W. Ballard of Dartmouth College, New Hampshire, who himself authored several series of normal stages. They are subtly different from those published in Harrison (1969). Original page $27.9 \times 21.4 \mathrm{~cm}$. Gift of Michael Dietrich.

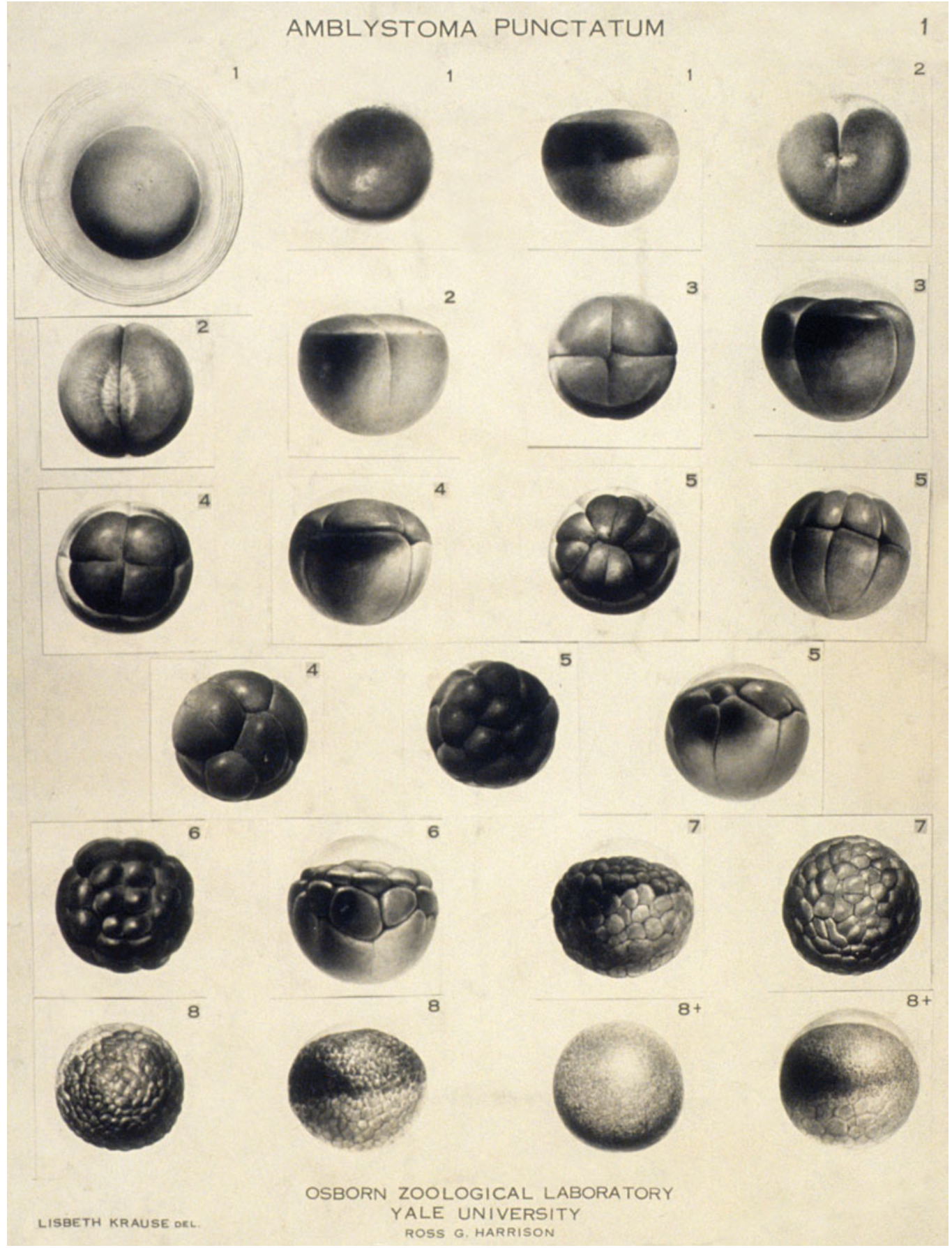

Remarkably, the stages had nevertheless long been in general use. The more elaborate experiments became, the more necessary it was to standardize stages of operation and of assay, within a single experiment, through an experimental series and to establish a "common language"” between laboratories (Pollister and Moore, 1937, p. 489), including those working on different, but closely related, species. Harrison's students received various salamander projects involving late stages, for which fine distinctions matter more. So his correspondence is full of inquiries from researchers who feared that their results would remain unintelligible until he published the stages. In response he gave out 
Tafel I. Normentafel für Rana fusca.

Alle Abbildungen wurden unter dem Binokular $\mathrm{F}=55 / \mathrm{Ok} .1$ mit dem Abbeschen Zeichenapparat gezeichnet. Vergr. etwa 6 fach.
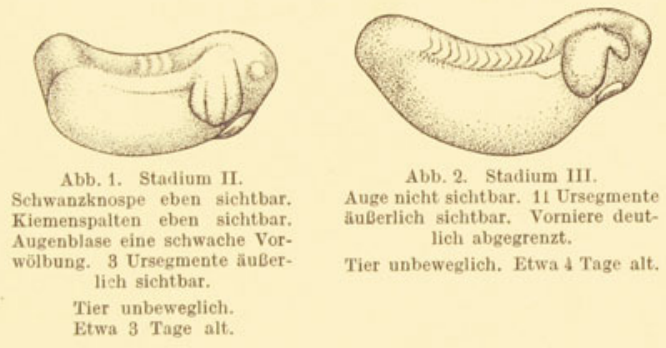

Auge nicht sichtbar. 11 Ursegmente sich abgegrenzt.
lich a

Tier unbeweglich. Etwa 4 Tage alt.
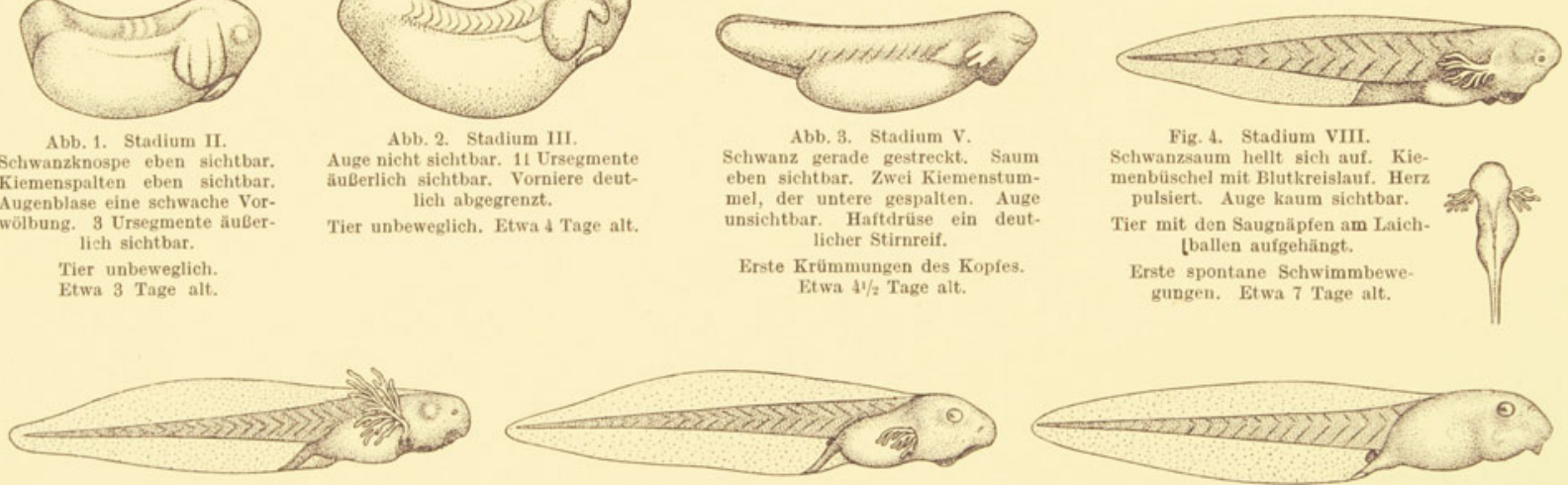

Abb. 5. Stadium IX.

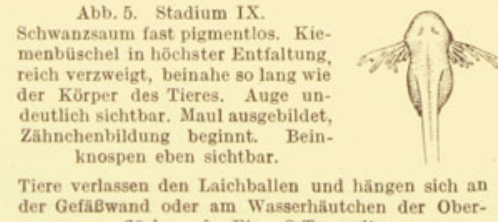

Abb. 6. Stadium $\mathrm{X}$. Kiemenbüschel halb überwachsen. Auge deutlich sichtbar. Cornea in Aufhellung. Beinknospen sichtbar. Tiere beginnen umherzuschwimmen, sind meist noch an den Saugnäpfen aufgehăngt.

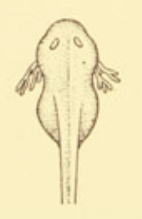

Abb. 7. Stadium XI. Nur Rest der linken Kieme äuBerlich eben noch sichtbar. Auge scharf abgegrenzt. Darm sichtbar. Saugnāpfe fast völlig rückgebil
Beinknospen kleine Höcker. Tiere schwimmen lebhaft umber.

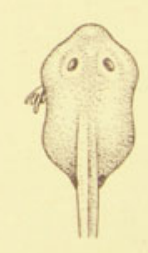

Fig. 20. Viktor Hamburger's small "normal plate for Rana fusca". From Hamburger (1925), p. 157, by kind permission of Springer Science and Business Media.

Krause's drawings free of charge to nearly 90 laboratories, mainly in the United States and Germany (Fig. 19). ${ }^{3}$ In the early 1940 s Harrison's stages were in fact published. Since experiments depended on staging, the new manuals of experimental embryology reproduced drawings of his and other series (e.g., Hamburger, 1942, pp. 196-204). So while the failure to publish formally might at first seem to indicate that the stages were a low priority, the effort put into communicating them by other means shows that they had become indispensable.

Experimenters in the other most important laboratory, German zoologist Hans Spemann's institute in Freiburg in Baden (Fäßler, 1997), took similar initiatives. In 1924, during his doctoral research, Viktor Hamburger made a small normal plate for the frog Rana fusca (Fig. 20) because he wanted to operate on precisely defined stages (Hamburger, 1925, pp. 157-158; 1992, p. 273). Later, for grafting between two newt species, he and a student, Eckart Rotmann, needed normal stages of limb development and another student, Salome Glücksohn (later Waelsch), was set to extend Harrison's stages (Glücksohn, 1931). Unhappy with this gendered division of labour, she would contrast her "rather boring descriptive study" with Rotmann's "quite exciting experimental problem" (Waelsch, 1992, p. 1; Hamburger, 1992, p. 274). But Hamburger had spent a little of his own time in a similar way and kept an appreciation of normal plates when he moved to the United States. In the late 1940s lowa zoologist Howard Hamilton was revising Chicago embryologist Frank Lillie's standard textbook on chick embryology and Hamburger persuaded him to replace the unillustrated table it contained with a series of normal stages that they published separately too (Hamburger and Hamilton, 1951; Hamburger, 1992) (Fig. 21).

The makers of the new normal stages were inspired by Keibel's
Normentafeln, but also dissatisfied with them. Even the volumes on the chick and a newt had not become popular. This was only partly because they were relatively inaccessible and unwieldy; the pictures were also reckoned inadequate for rapid identification and/or inconveniently spaced (e.g., Hamburger and Hamilton, 1951, p. 50; Glücksohn, 1931, p. 353). Their authors had not focused on diagnostically decisive parts; they generally used lithography, which achieved a high degree of verisimilitude at the expense of definition; and in a few cases they were simply not as expert.

Experimentalists' complaints point to their "ground rules" (Hamburger, 1992, p. 275). First, rapid staging in the course of an experiment should be possible from sharply defined external features alone. This meant using characters that were changing prominently, for the chick at fairly early stages the number of somites, later the limb buds (Fig. 21). Second, successive stages should represent the whole period of interest closely. This meant good coverage of busy periods when external morphology might change little, while avoiding minor differences as criteria. Hamburger and Hamilton defined each stage by a short description plus a photograph of a whole embryo that "appeared typical" (Hamburger and Hamilton, 1951, p. 52). Some extra pictures of key diagnostic features were given (Fig. 21). ${ }^{4}$

This work turned large-format monographs into 20-page articles containing drawings of external morphology plus stage

Note 3: Distribution list: Yale University Library, Manuscripts and Archives: Harrison Papers (MS 263), series III, box 38, folder 258.

Note 4: Eyal-Giladi and Kochav (1976) provided a normal table for preprimitive-streak stages. 

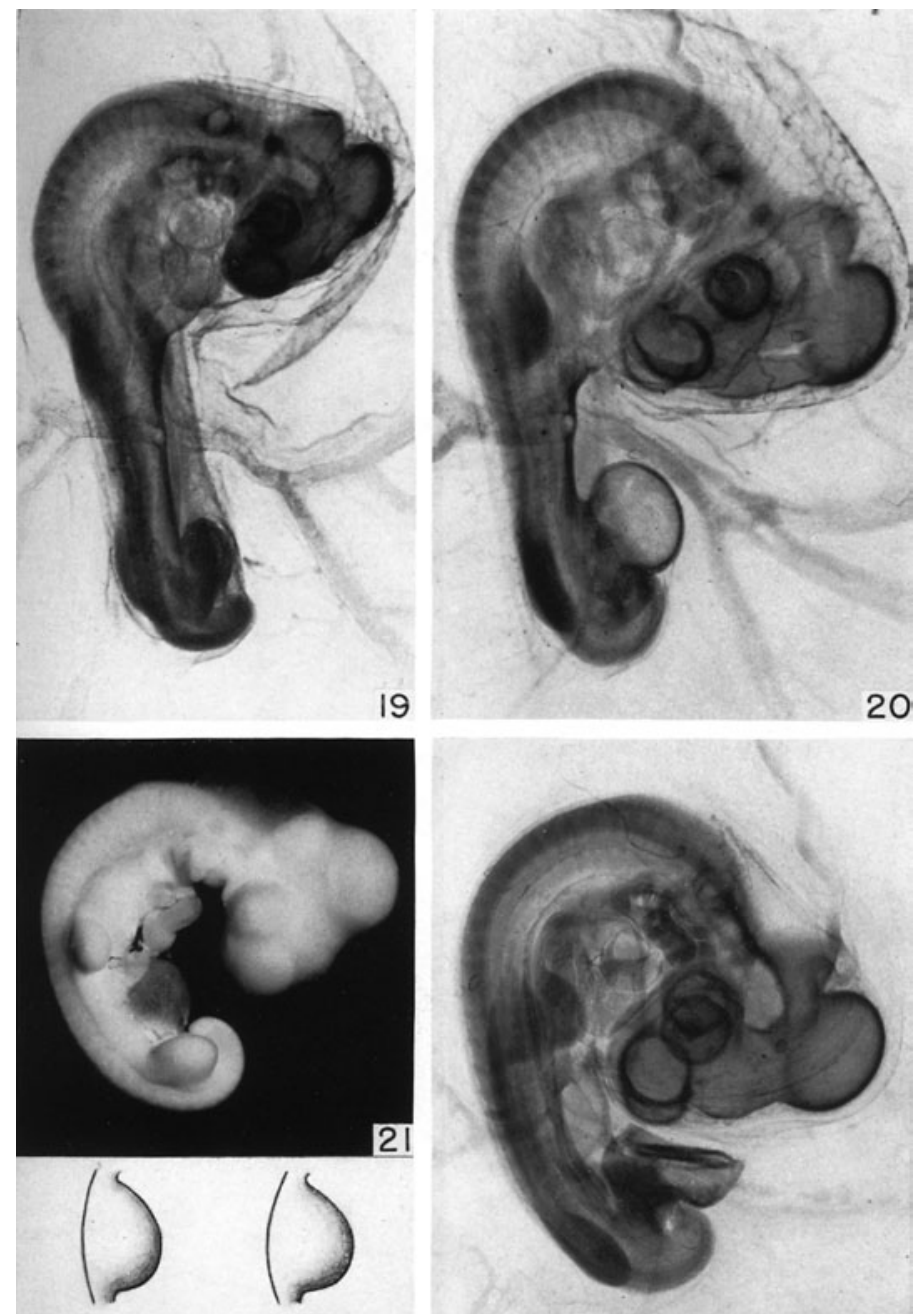

WING

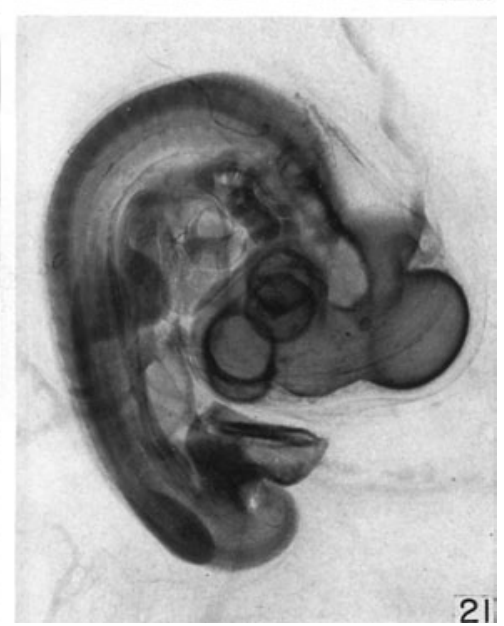

TABLE 1

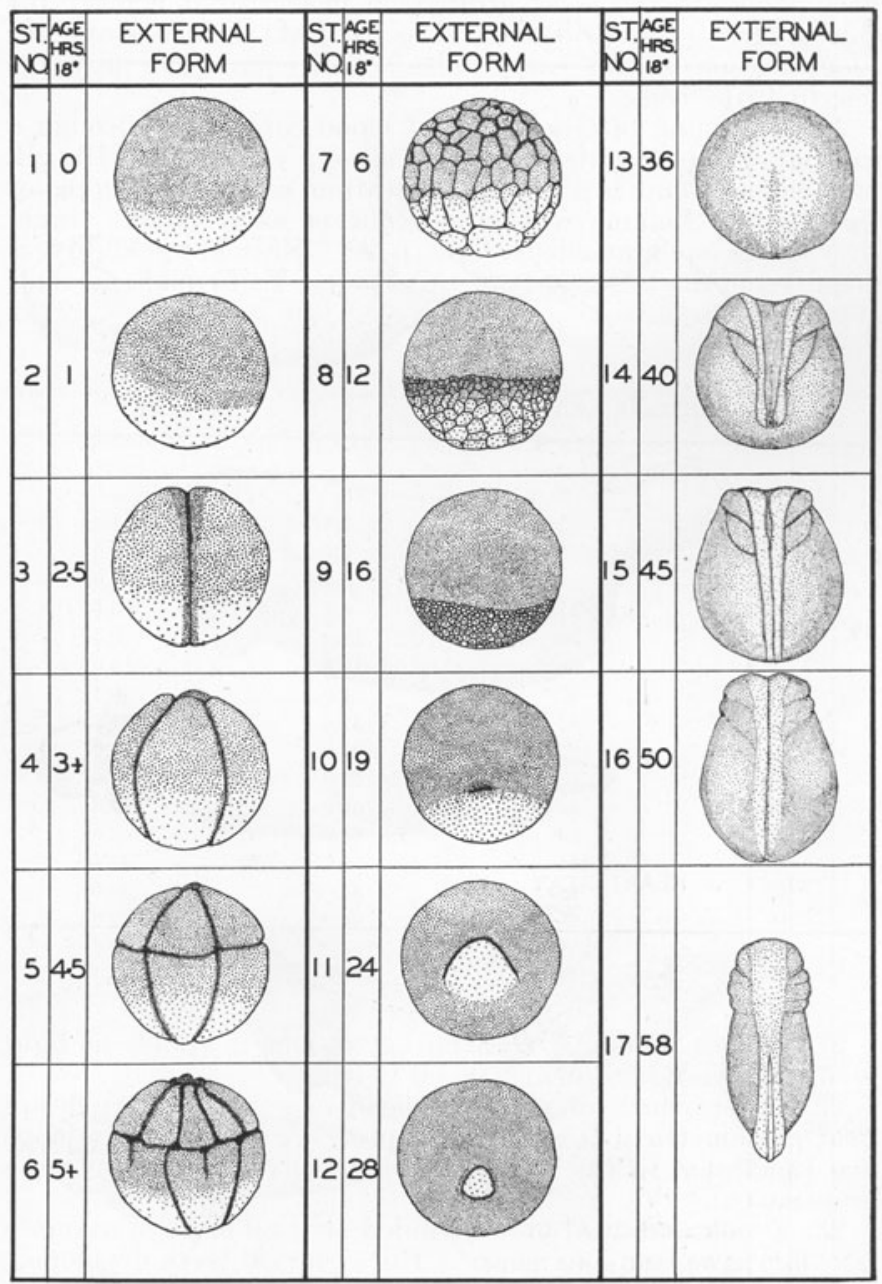

Fig. 21 (Left). Hamburger and Hamilton chick stages 19 to 21. The photographs (both cleared and opaque for stage 21) are supplemented by drawings of the diagnostically important limb buds. From Hamburger and Hamilton (1951), p. 79.

Fig. 22 (Right). Table for the normal development of Rana sylvatica. From Pollister and Moore (1937), p. 493, by permission of the Syndics of Cambridge University Library.

criteria. By the mid-twentieth century The Anatomical Recordand the Journal of Morphologywere filling with short articles reporting "stages in" or "tables for the normal development of" various lower vertebrates. These 'tables' were not summaries of internal development in Oppel's sense but drawings plus information about age and/or length (Fig. 22). Exceptions prove the rule. Few can have held their breath while the Berlin anatomist Friedrich Kopsch took till 1952 to complete the Normentafe/on the frog Rana fuscathat he had promised Keibel in 1897 (Kopsch, 1952). Far more significant was the 1956 Xenopus normal table, which combined continuity with the older normal plates in its production with innovation in its use.

If Harrison demonstrated the power of a leading researcher and teacher to promote normal stages, the Xenopus project illustrates the strength of scientific internationalism. The Hubrecht Laboratory in Utrecht, as seat of the I.I.d'E. (from 1968 the International Society of Developmental Biologists), home of the
Central Embryological Collection and from 1949 to 1980 publisher of the General Embryological Information Servicenewsletter, had re-established itself after World War II as the closest thing to a global embryological institution. Producing a normal table would keep up the prewar tradition and enhance the international mission. The director, Pieter Nieuwkoop, chose Xenopus laevis, a South African amphibian that pregnancy testing had introduced into the laboratories of the world and hormone injection would induce to lay eggs all year round (Nieuwkoop and Faber, 1956, p. 1; Gurdon and Hopwood, 2000).

Deciding to use embryos laid in South Africa, Nieuwkoop sent the master's student Job Faber to Jonkershoek Fish Hatchery near Stellenbosch, which was already producing adult Xenopus for export, and he stayed for eight months. They had determined stages up to the tailbud in Utrecht and Faber established the rest in the field, following Harrison's model. Faber photographed anaesthetized living embryos and on his return to Utrecht used 

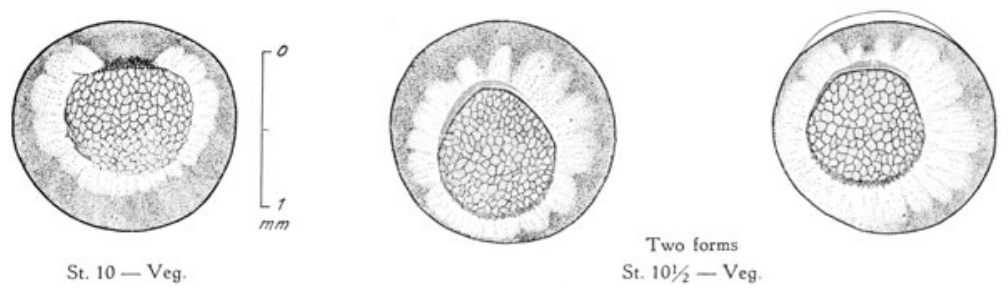

St. $10-$ Veg.

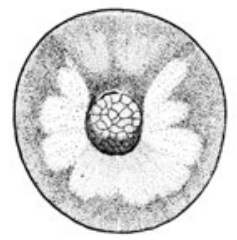

St. $12-$ Veg.

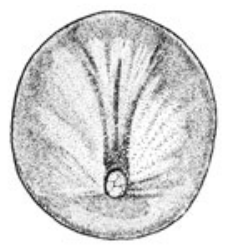

St. $121 / 2-$ Post.-dors.

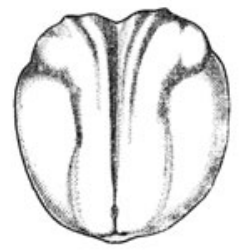

St. 15 - Post.-dors.

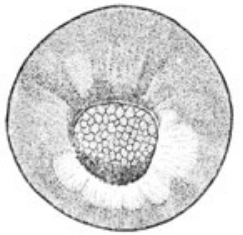

St. $11 \frac{1}{2}-$ Veg.

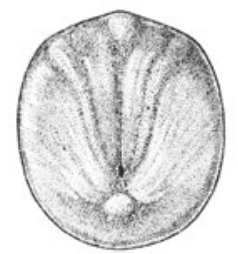

St. 13 - Posterio-dorsal view (Post--dors.)

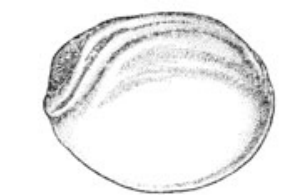

St. 14 - Lateral view (left side) (Lat.)

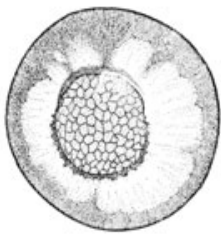

St. $11-$ Veg

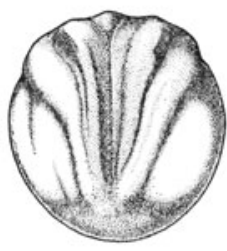

St. 14 - Post.-dors.

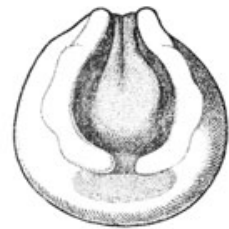

St. 15 - Anterior view (Ant.)

Fig. 23. Nieuwkoop and Faber stages of the South African clawed frog, Xenopus

laevis. For these relatively early embryos, from initial gastrula to early neural-fold stage, staging followed Harrison's closely. From Nieuwkoop and Faber (1956), pl. III.

molecular biologists who saw a field ripe for their skills. It took over the problems and practices of experimental embryology but claimed a role in explaining development and differentiation throughout the living world. Since the principles were supposed to be universal, it could take any convenient species (Keller, 1995). The normal table helped Xenopus oust seasonal local amphibians and become one of the few model systems on which by the 1980s most developmental biology was done (Gurdon and Hopwood, 2000). Normal stages are, more generally, among the most widely used publications; they are even being produced in the form of posters that advertise the journal Developmental Dynamics (http://www3.interscience .wiley.com/cgi-bin/jhome/ 38417). They help order experiments and communicate the results. As long as they remain uncontroversial, they reduce controversy over other issues.

It is instructive to compare the experimentalists' normal stages with a mid-twentieth-century series produced in a different field: human embryology as practised by Mall's successor, George L. Streeter (Corner, 1954), at the Carnegie Department, a "bureau of standards" for the field (O'Rahilly, 1988, $p$. 93). The problem here, to order a collection that was expanding to some 8,000 specimens with associated drawings and models (Fig. 24), was much more like Keibel's authors' than the experimentalists', except that numbers were much larger and interspecies comparison was a secondary concern (Corner, 1944).

In 1942, shortly after retiring, Streeter began to publish a survey of human embryos that superseded the preliminary stages Mall had set up. This replaced the Normentafe/seriations, which had the disadvantage that if a new embryo was more advanced in one respect but less so in another it might not fit the norms. Yet, with the embryo collector's

the drawing experience gained during a course in taxonomic botany to make pencil drawings, which the Zoology Department's scientific illustrator, J. J. Prijs, took into ink for publication as ten fold-out plates (Fig. 23). ${ }^{5}$ These plus the 27 pages of internal and external stage criteria correspond to the Harrison stages. The bulk of the 252-page book was devoted to "the systematic description of the internal development", on which Nieuwkoop had organized international collaboration by distributing sections among 24 contributors in nine countries for analysis. This was equivalent to Keibel's Tabellenbut with little attention to variation. Nieuwkoop and Faber included "a comparative table of anuran normal tables", but lowa embryologist Emil Witschi's proposal that, for "the comparative and generalizing evaluation of developmental processes" and for teaching, standard series of normal stages-he counted over 50-should themselves be standardized across the vertebrates, was not widely taken up (Witschi, 1956).

During the 1960s experimental embryology was recast as 'developmental biology', an initiative of self-consciously 'modern' embryologists and geneticists, biochemists, cell biologists and respect for the individual specimen, Streeter at first fought shy of "the term stage, with its implication of precision". Instead, he segregated embryos more flexibly into "age groups" that "represent levels in their structural organization as a whole". He borrowed the term 'horizons' from geology and sought, like fossils for strata, several morphological criteria for each one (Streeter, 1942, pp. 213-214). Streeter eventually concluded that "a definite and invariable schedule of organ correlation does occur", i.e., that for each developmental level he could distinguish "a syndrome of characters" (Streeter, 1948, p. 135). But he defined the later embryonic horizons by ranges of point scores for the presence of marked transformations in key organs (Streeter, 1951, p. 169).

Since many specimens had been sectioned, internal were more important than external criteria. Streeter concentrated on "characters that can be clearly and easily recognized and that do

Note 5: Nieuwkoop and Faber, 1956; additional information from Job Faber to the author, 14 July 1999. 


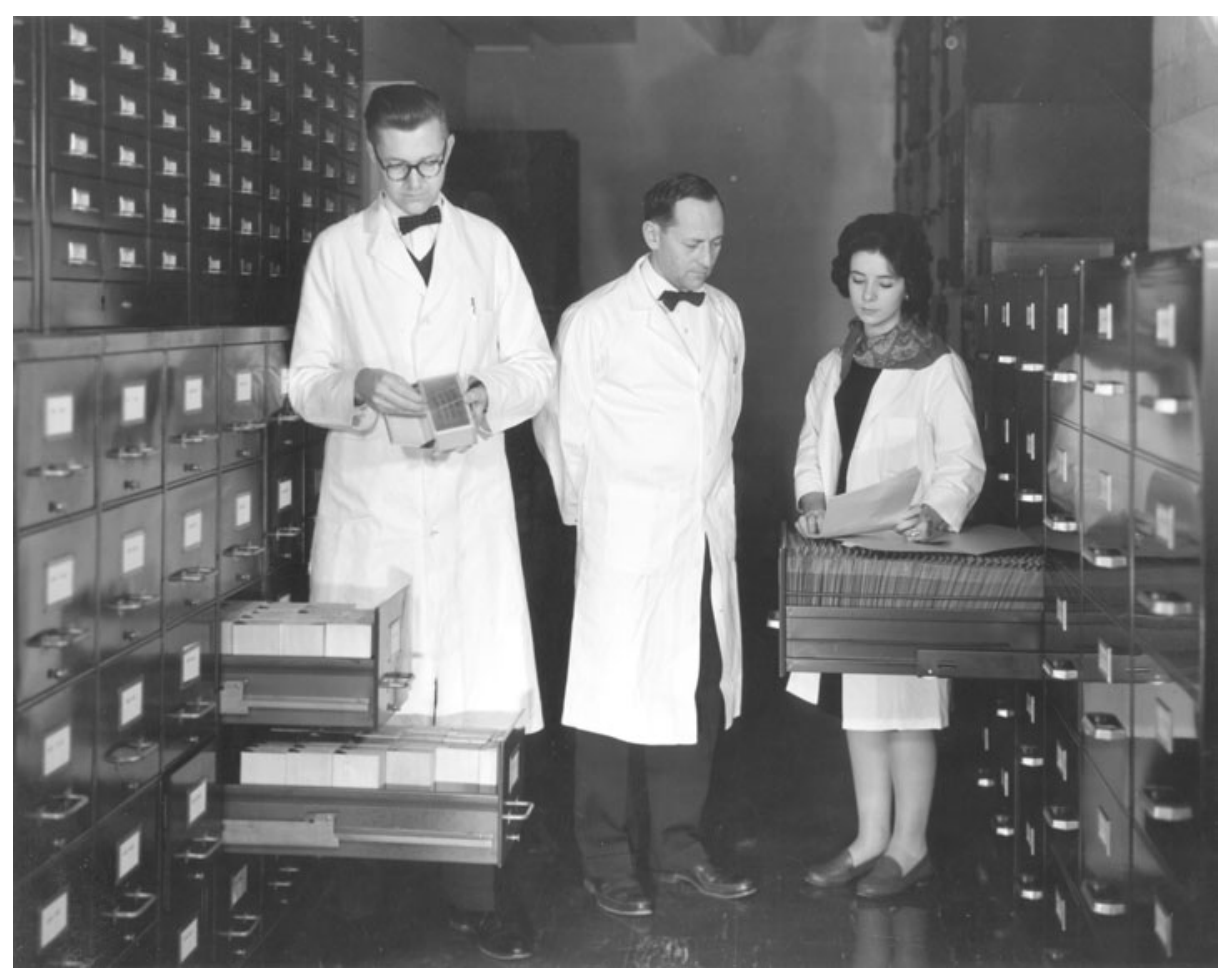

Fig. 24. The Carnegie collection of human embryos. The cabinets on the left contain the slides and those on the right the associated records; the models that formed an important part of the collection are not shown. Two scientists are posed with assistant Ellen P. Monaghan; only a few researchers, notably Elizabeth Ramsey, were women. Carnegie Institution of Washington Archives.

not require special staining techniques, or elaborate reconstructions, for their identification", i.e., features that could easily be scored as present or absent in sections (Streeter, 1948, p. 137). Yet though the aim was to order specimens efficiently, this could presumably take hours rather than seconds. Streeter's papers in the Department's lavish Contributions to Embryologyoffer photographs of whole embryos in several views and of sections and drawings of the more significant structural and diagnostic features (Fig. 25).

After Streeter's death, Ronan O'Rahilly took over the collection and the project, which was no longer at the centre of the Department's research, extending it to the earliest embryos and revising the other horizons. He went back to 'stages', because the "term is simpler, clearer, of widespread usage and can be employed as a verb", but prized the flexibility of Streeter's system. For the earliest stages a single criterion was enough, but later stages used more (O'Rahilly, 1973, p. 4; O’Rahilly and Müller, 1987). Carnegie stages eclipsed the few rival systems (O'Rahilly, 1973, pp. 7-8). Here, too, the Normentafe/design, which had originally inspired the project, was superseded.

\section{Discussion}

Normal plates, tables and stages have been moulded by their producers' agendas. Though proposed throughout the nineteenth century, developmental divisions were heterogeneous and had little general force. Demand for reform came from German anatomists in the 1890s, who complained that the proliferation of arbitrary 'stages' was impeding communication. Working in evolutionary morphology, Franz Keibel designed books to reinvestigate the relations of ontogeny and phylogeny, provide materials for the study of individual embryonic variation and as general laboratory aids. Though he and his closest collaborators avoided setting up stages, the plates were ironically the starting points from which in the second quarter of the twentieth century embryologists of different persuasions created staging systems. Researchers in experimental and in human embryology revised the format according to their contrasting agendas and the different kinds of work that amphibian and chick versus human embryos allowed. Experimentalists reduced the large volumes to a few pages of text plus drawings or photographs that they could use to stage living embryos rapidly for operations. Human embryologists adapted the Normentafe/to the arrangement of a much larger collection in cohorts of not-quitesynchronously-developing specimens.

Standards of development have not only been shaped by disciplinary change, they have shaped it too. The first so-called Normentafel, by Wilhelm His, created a framework for assessing new specimens and so fostered work in a reformed human embryology. Keibel's normal plates promoted an international revitalization of comparative vertebrate embryology, which though cut short by World War I created institutes and a professional society that have endured. In most histories experimental embryology still makes all the running by the early 1900 s, but in these very years a major step towards independence for embryology was taken through work that is still too often disparaged as merely descriptive. Collaboration on normal plates paved the way. Later, normal stages were essential tools in the domestication of organisms for developmental biology. We see embryos with these pictures and descriptions in mind.

If normal plates, tables and stages have been so important, why has their history not attracted much interest before? In part, surely, because they are treated as tools rather than results, but in part, also, because they have generally been uncontentious; agreement to recognize them as standards was fairly easily achieved. The trouble over Haeckel's plates-which were not, he protested, intended for exact research-shows what could happen when the conditions for maximum controversy were met. Following His and Albert Oppel, Keibel's collaborative project established the desirability of norms. But though some of his plates are still useful, they did not suit experimentalists because their authors, who lacked authority in experimental communities, had produced them for a different purpose. In the mid-twentieth century consent to stage systems appears to have depended on their proposers' occupying strategic institutional positions, which widely-used stages then reinforced. At the Hubrecht Laboratory 
A
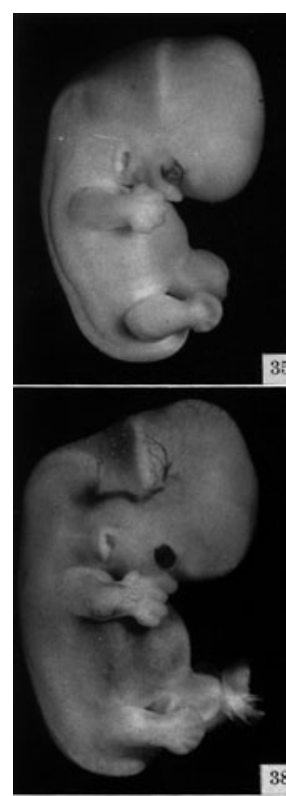

35
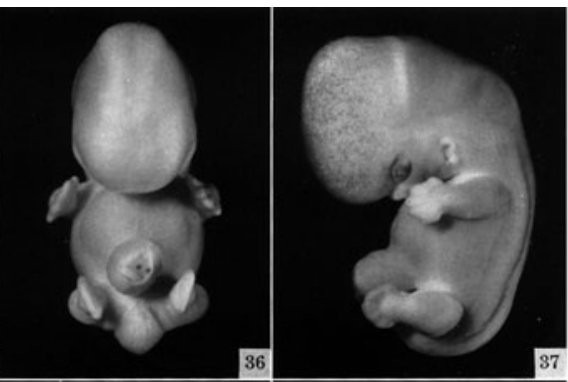

37
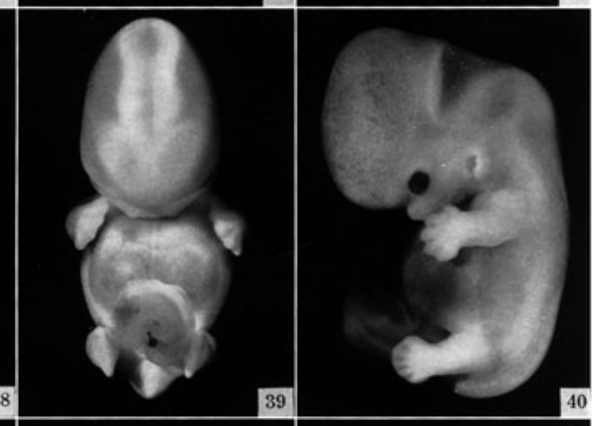

40

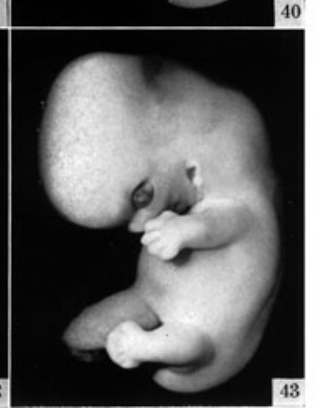

B

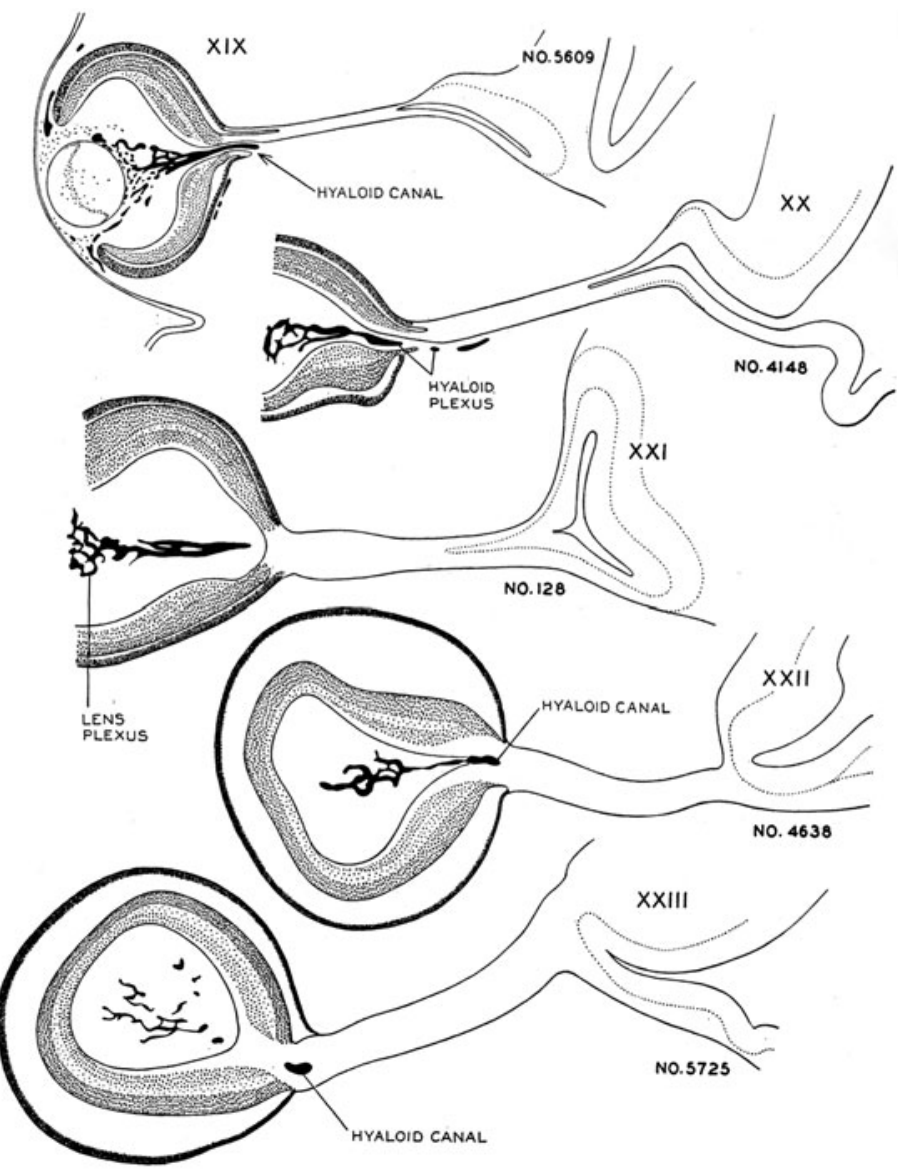

Fig. 25. Developmental horizons in human embryos. (A) "Photographs of three embryos belonging to horizon XIX"; the numbers (35-43) are figure numbers. (B) "Drawings of sections through the eye and optic nerve in age groups xix to xxiii." The optic nerve was one of eight arbitrarily chosen key structures that Streeter assigned point scores. Roman numerals stand for horizons, Arabic are specimen numbers in the Carnegie collection. From Streeter (1951), pl. I, XIX and fig. 4 on p. 174, by permission of the Syndics of Cambridge University Library.

and especially the Carnegie Department, those responsible for rare material were uniquely well placed. Successful stages were also proposed by individual researchers-Ross Harrison is the prime example - at the centre of webs of training and research.

Much of the time, in most areas of developmental biology today, normal stages meet users' needs and agreement can be assumed. Knowing how these tools were made just enhances our appreciation of the culture of the science. Yet in some fields staging systems are either lacking or experienced as inadequate. More generally, attempts to standardize stages across the vertebrates have met with only limited success, in part because this would demand compromise across entrenched divisions between species. Concerns related to Oppel's about the usability of reported results, for example, of gene expression data, are widespread. Individual variation is rising up the research agenda again. On these fronts, at least, history could help developmental biologists think more deeply about the future as well as the past.

\section{Acknowledgements}

See Hopwood (2005) for fuller discussion and more references. I thank the institutions named in the notes and figure captions for permission to quote from manuscripts and reproduce items in their care, Adrian Newman for preparing the figures and Scott Gilbert, Brian Hall and an anonymous referee for helpful comments. This research was supported by the Wellcome Trust (grant numbers 063293 and 074298).

\section{References}

APPEL, T.A. (1987). The Cuvier-Geoffroy Debate: French Biology in the Decades before Darwin. Oxford University Press, New York.

BADISCHER ARCHITECTEN- UND INGENIEUR-VEREIN, OBERRHEINISCHER BEZIRK, FREIBURG IM BREISGAU, Ed. (1898). Freiburg im Breisgau. Freiburg.

BAER, K.E. VON. (1828). Über Entwickelungsgeschichte der Thiere. Beobachtung und Reflexion, part 1. Königsberg: Gebrüder Bornträger.

BININDA-EMONDS, O.R.P., JEFFERY, J.E., COATES, M.I. and RICHARDSON, M.K. (2002). From Haeckel to event-pairing: The evolution of developmental sequences. Theory Biosci. 121: 297-320.

BUDGETT, J.S. (1901). On the breeding-habits of some West-African fishes, with an account of the external features in the development of Protopterus annectens and a description of the larva of Polypterus lapradei. Trans. Zool. Soc. Lond. 16: 115-136.

CHURCHILL, F.B. (1994). The rise of classical descriptive embryology. In $A$ Conceptual History of Modern Embryology (Ed. S.F. Gilbert). Johns Hopkins University Press, Baltimore, pp. 1-29.

CLARKE, A.E. (1987). Research materials and reproductive science in the United 
States, 1910-1940. In Physiology in the American Context, 1850-1940(Ed. G.L. Geison). American Physiological Society, Bethesda, Md. pp. 323-350.

CORNER, G.W. (1944). Ourselves Unborn: An Embryologist's Essay on Man. Yale University Press, New Haven

CORNER, G.W. (1951). Preface to G.L. Streeter, Developmental Horizons in Human Embryos: Age Groups XI to XXIII. Collected Papers from the Contributions to Embryology Published by the Carnegie Institution of Washington. Carnegie Institution of Washington, Washington D.C., pp. iii-iv.

CORNER, G.W. (1954). George Linius Streeter, 1873-1948. Biogr. Mem. Nat/ Acad. Sci. 28: 260-287.

DASTON, L. and GALISON, P. (1992). The image of objectivity. Representations (Berkeley) 40: 81-128.

DUDEN, B., SCHLUMBOHM, J. and VEIT, P. ed. (2002). Geschichte des Ungeborenen. Zur Erfahrungs- und Wissenschaftsgeschichte der Schwangerschaft, 17.-20. Jahrhundert. Vandenhoeck \& Ruprecht, Göttingen.

EYAL-GILADI, H. and KOCHAV, S. (1976). From cleavage to primitive streak formation: A complementary normal table and a new look at the first stages of the development of the chick. Dev. Biol. 49: 321-337.

FAASSE, P., FABER, J. and NARRAWAY, J. (1999). A brief history of the Hubrecht Laboratory. Int. J. Dev. Biol. 43: 583-590.

FÄßLER, P.E. (1997). Hans Spemann 1869-1941. Experimentelle Forschung im Spannungsfeld von Empirie und Theorie. Ein Beitrag zur Geschichte der Entwicklungsphysiologie zu Beginn des 20. Jahrhunderts. Springer, Berlin.

GLÜCKSOHN, S. (1931). Äussere Entwicklung der Extremitäten und Stadieneinteilung der Larvenperiode von Triton taeniatus Leyd. und Triton cristatus Laur. Arch. Entwick/ungsmech. Org. 125: 341-405.

GOULD, S.J. (1977). Ontogeny and Phylogeny. Belknap Press of Harvard University Press, Cambridge, Mass.

GROSSER, O. and TANDLER, J. (1909). Normentafe/zur Entwicklungsgeschichte des Kiebitzes (Vanellus cristatus Meyer). Fischer, Jena.

GURDON, J B. and HOPWOOD, N. (2000). The introduction of Xenopus laevis into developmental biology: Of empire, pregnancy testing and ribosomal genes. Int. J. Dev. Biol. 44: 43-50.

GURSCH, R. (1981). Die Illustrationen Ernst Haeckels zur Abstammungs- und Entwicklungsgeschichte. Diskussion im wissenschaftlichen und nichtwissenschaftlichen Schrifttum. Lang, Frankfurt am Main.

HAECKEL, E. (1874). Anthropogenie oder Entwickelungsgeschichte des Menschen. Gemeinverständliche wissenschaftliche Vorträge über die Grundzüge der menschlichen Keimes- und Stammes-Geschichte. Engelmann, Leipzig.

HAECKEL, E. (1875). Die Gastrula und die Eifurchung der Tiere. Jenaische $Z$. Naturwiss. 9: 402-508.

HAECKEL, E. (1891). Anthropogenie oder Entwickelungsgeschichtedes Menschen. Keimes- und Stammes-Geschichte, 4th edn, 2 parts. Engelmann, Leipzig.

HALL, B.K. (2001). John Samuel Budgett (1872-1904): In pursuit of Polypterus. BioScience 51: 399-407.

HAMBURGER, V. (1925). Über den Einfluss des Nervensystems auf die Entwicklung der Extremitäten von Rana fusca. W. Roux'Arch. Entwicklungsmech. Org. 105: 149-201.

HAMBURGER, V. (1942). A Manual of Experimental Embryology. University of Chicago Press, Chicago.

HAMBURGER, V. (1992). Afterword: The stage series of the chick embryo. Dev. Dyn. 195: 273-275.

HAMBURGER, V. and HAMILTON, H.L. (1951). A series of normal stages in the development of the chick embryo. J. Morph. 88: 49-92.

HARRISON, R.G. (1918). Experiments on the development of the fore limb of Amblystoma, a self-differentiating equipotential system. J. Exp. Zool. 25: 413459.

HARRISON, R.G. (1925). The development of the balancer in Amblystoma, studied by the method of transplantation and in relation to the connective-tissue problem. J. Exp. Zool. 41: 349-427.

HARRISON, R.G. (1969). Organization and Development of the Embryo (Ed. S. Wilens). Yale University Press, New Haven.

HIS, W. (1868). Untersuchungen über die erste Anlage des Wirbelthierleibes. Die erste Entwickelung des Hühnchens im Ei. Vogel, Leipzig.
HIS, W. (1872). Überdie Aufgaben und Zielpunkte derwissenschaftlichen Anatomie. Rede, gehalten beim Antritt der anatomischen Professur der Universität Leipzig den 4. November 1872. Vogel, Leipzig.

HIS, W. (1880). Anatomie menschlicher Embryonen, vol. 1: Embryonen des ersten Monats. Vogel, Leipzig.

HIS, W. (1882). Anatomie menschlicher Embryonen, vol. 2: Gestalt- und Grössenentwicklung bis zum Schluss des 2. Monats. Vogel, Leipzig.

HIS, W. (1885). Anatomie menschlicher Embryonen, vol. 3: Zur Geschichte der Organe. Vogel, Leipzig.

HIS, W. (1886). Die Entwicklung der zoologischen Station in Neapel und das wachsende Bedürfniss nach wissenschaftlichen Centralanstalten. Biol. Centralbl. 6: 545-554.

HIS, W. (1901). Ueber wissenschaftliche Centralanstalten und speciell über Centralanstalten zur Förderung der Gehirnkenntniss. Berichte über die Verhandlungen dermathematisch-physischen Classe der Königlich Sächsischen Gesellschaft der Wissenschaften zu Leipzig 53: 413-436.

HOPWOOD, N. (1999). "Giving body" to embryos: Modelling, mechanism and the microtome in late nineteenth-century anatomy. Isis 90: 462-496.

HOPWOOD, N. (2000). Producing development: The anatomy of human embryos and the norms of Wilhelm His. Bull. Hist. Med. 74: 29-79.

HOPWOOD, N. (2002). Embryos in Wax: Models from the Ziegler Studio, with a Reprint of "Embryological Wax Models" by Friedrich Ziegler. Whipple Museum of the History of Science, Cambridge; Institute of the History of Medicine, Bern.

HOPWOOD, N. (2005). Visual standards and disciplinary change: Normal plates, tables and stages in embryology. Hist. Sci. 43: 239-303.

HOPWOOD, N. (2006). Pictures of evolution and charges of fraud: Ernst Haeckel's embryological illustrations. Isis 97: 260-301.

HUBRECHT, A.A.W. (1894). Studies from the Zoological Laboratory in the University of Utrecht: IV. Spolia nemoris. Q. J. MicrosC. Sci. 36: 77-125.

KEIBEL, F. (1893). Studien zur Entwicklungsgeschichte des Schweines (SuS scrofa domesticus). Morph. Arb. 3: 1-139.

KEIBEL, F. (1895a). Studien zur Entwicklungsgeschichte des Schweines. (SuS scrofa domesticus.) II. Morph. Arb. 5: 17-168.

KEIBEL, F. (1895b). Normentafeln zur Entwickelungsgeschichte der Wirbeltiere. Anat. Anz. 11: 225-234.

KEIBEL, F. (1896). Mitteilungen über die "Normentafeln zur Entwickelungsgeschichte der Wirbeltiere". Anat. Anz. 11: 593-596.

KEIBEL, F. (1897). Normentafe/ zur Entwicklungsgeschichte des Schweines (Sus scrofa domesticus). Fischer, Jena

KEIBEL, F. (1898). Das biogenetische Grundgesetz und die Cenogenese. Ergeb. Anat. Entwicklungsgesch. 7: 722-792.

KEIBEL, F. (1899). Zu Mehnerts Bemerkungen über meine Kritiken und Referate. Anat. Hefte 12: 567-573.

KEIBEL, F. (1916). Gustav Albert Schwalbe †. Anat. Anz. 49: 210-221.

KEIBEL, F. and ABRAHAM, K. (1900). Normentafe/ zur Entwicklungsgeschichte des Huhnes (Gallus domesticus). Fischer, Jena.

KEIBEL, F. and ELZE, C. (1908). Normentafel zur Entwicklungsgeschichte des Menschen. Fischer, Jena.

KELLER, E.F. (1995). Refiguring Life: Metaphors of Twentieth-Century Biology. Columbia University Press, New York.

KERR, J.G. (1901). The development of Lepidosiren paradoxa. Part II. With a note upon the corresponding stages in the development of Protopterus annectens. Q. J. Microsc. Sci. 45: 1-40.

KERR, J.G. (1909). Normal Plates of the Development of Lepidosiren paradoxa and Protopterus annectens. Fischer, Jena.

KERR, J.G. (1950). A Naturalist in the Gran Chaco. Cambridge University Press, Cambridge.

KOPSCH, F. (1952). Die Entwicklung des braunen Grasfrosches Rana fusca Roesel, dargestellt in der Art derNormentafeln zur Entwicklungsgeschichte der Wirbeltiere. Thieme, Stuttgart.

LANGE JR, D. DE and NIERSTRASZ, H.F. (1932). Tabellarische Uebersicht der Entwicklung von Tupaia javanica Horsf. Oosthoek, Utrecht.

LATOUR, B. (1987). Science in Action: How to Follow Scientists and Engineers 


\section{N. Hopwood}

through Society. Harvard University Press, Cambridge, Mass.

LENOIR, T. (1989). The Strategy of Life: Teleology and Mechanics in NineteenthCentury German Biology. University of Chicago Press, Chicago.

LEWIS, F.T. (1916). Charles Sedgwick Minot. Anat. Rec. 10: 133-164.

MACLEOD, R. (1994). Embryology and empire: The Balfour Students and the quest for intermediate forms in the laboratory of the Pacific. In Darwin's Laboratory: Evolutionary Theory and Natural History in the Pacific (Eds. Macleod and P. F. Rehbock). Univ. of Hawai'i Press, Honolulu, pp. 140-165.

MAIENSCHEIN, J. (1991). Transforming Traditions in American Biology, 18801915. Johns Hopkins University Press, Baltimore.

MAIENSCHEIN, J. (1994). The origins of Entwicklungsmechanik. In A Conceptual History of Modern Embryology (Ed. S.F. Gilbert). Johns Hopkins University Press, Baltimore, pp. 43-61.

MEHNERT, E. (1895). Die individuelle Variation des Wirbelthierembryo. Eine Zusammenstellung. Morph. Arb. 5: 386-444.

MEHNERT, E. (1897). Kainogenese. Eine gesetzmässige Abänderung der embryonalen Entfaltung in Folge von erblicher Uebertragung in der Phylogenese erworbener Eigenthümlichkeiten. Morph. Arb. 7: 1-156.

MEHNERT, E. (1898). Allgemeine Entwicklungsgeschichte. II. Variation, Heredität. A. Variation. Jahresberichte über die Fortschritte der Anatomie und Entwicklungsgeschichte, new ser., 3: 327-336.

MEHNERT, E. (1899). Bemerkungen zu Keibels Kritiken und Referaten. Anat. Hefte 12: 549-565.

MINOT, C.S. and TAYLOR, E. (1905). Normal Plates of the Development of the Rabbit (Lepus caniculus L.). Fischer, Jena.

MORGAN, L.M. (2002). "Properly disposed of": A history of embryo disposal and the changing claims on fetal remains. Med. Anthropol. 21: 247-274.

NAUCK, E.T. (1937). Franz Keibel. Zugleich eine Untersuchung über das Problem des wissenschaftlichen Nachwuchses. Fischer, Jena.

NIEUWKOOP, P.D. (1961). "L'Institut International d'Embryologie" (1911-1961). General Embryological Information Service 9: 265-269.

NIEUWKOOP, P.D. and FABER, J. Eds. (1956). Normal Table of Xenopus laevis (Daudin): A Systematical and Chronological Survey of the Development from the Fertilized Egg till the End of Metamorphosis. North-Holland, Amsterdam.

NOE, A. (2005). The human embryo collection at the Department of Embryology of the Carnegie Institution of Washington. In Centennial History of the Carnegie Institution of Washington, vol. 5: The Department of Embryology (Eds. J. Maienschein, M. Glitz and G.E. Allen). Cambridge University Press, Cambridge, pp. 21-61.

NYHART, L.K. (1995). Biology Takes Form: Animal Morphology and the German Universities, 1800-1900. University of Chicago Press, Chicago.

OPPEL, A. (1891). Vergleichung des Entwicklungsgrades der Organe zu verschiedenen Entwicklungszeiten bei Wirbeltieren. Fischer, Jena.

OPPEL, A. (1892). Dritter Theil: Entwicklungsgeschichte. Zweiter Abtheilung: Entwicklungsgeschichte der Wirbelthiere. Jahresbericht über die Fortschritte der Anatomie und Physiologie 20, section 1: 608-747.

O'RAHILLY, R. (1973). Developmental Stages in Human Embryos, Including a Survey of the Carnegie Collection. Part A: Embryos of the First Three Weeks (Stages 1 to 9). Carnegie Institution of Washington, Washington, D.C.

O'RAHILLY, R. (1988). One hundred years of human embryology. Iss. Rev. Teratol. 4: 81-128.

O'RAHILLY, R. and MÜLLER, F. (1987). Developmental Stages in Human Embryos. Including a Revision of Streeter's "Horizons" and a Survey of the
Carnegie Collection. Carnegie Institution of Washington, Washington, D.C.

PANDER, C.H. (1817). Beiträge zur Entwickelungsgeschichte des Hühnchens im Eye. Würzburg.

PETER, K. (1904). Normentafel zur Entwicklungsgeschichte der Zauneidechse (Lacerta agilis). Fischer, Jena.

PETER, K. (1929). Franz Keibel. Ein Nachruf. Anat. Anz. 68: 201-220.

POLLISTER, A.W. and MOORE, J.A. (1937). Tables for the normal development of Rana sy/vatica. Anat. Rec. 68: 489-496.

RAFF, R.A. (1996). The Shape of Life: Genes, Development and the Evolution of Animal Form. University of Chicago Press, Chicago.

RICHARDSON, M.K. and NARRAWAY, J. (1999). A treasure house of comparative embryology. Int. J. Dev. Biol. 43: 591-602.

ROUX, W. (1917). † Albert Oppel. Arch. Entwicklungsmech. Org. 42: 261-266.

RUSSELL, E.S. (1916). Form and Function: A Contribution to the History of Animal Morphology. Murray, London.

SAKURAI, T. (1906). Normentafel zur Entwicklungsgeschichte des Rehes (Cervus capreolus). Fischer, Jena.

SANES, J.R. (1992). On the republication of the Hamburger-Hamilton stage series. Dev. Dyn. 195: 229-230.

SCAMMON, R.E. (1911). Normal Plates of the Development of Squalus acanthias. Fischer, Jena.

SCHWALBE, G. (1898). Über Variation. Verh. Anat. Ges. 12: 2-15.

SCHWALBE, G. (1903). Ernst Mehnert †. Anat. Anz. 22: 387-392.

SEMON, R. (1896). Im australischen Busch und an den Küsten des Korallenmeeres. Reiseerlebnisse und Beobachtungen eines Naturforschers in Australien, NeuGuinea und den Molukken. Engelmann, Leipzig.

SOEMMERRING, S.T. (1799). Icones embryonum humanorum. Frankfurt am Main: Varrentrapp und Wenner.

STIEVE, H. (1929). Franz Keibel zum Gedächtnis. Z. Mikrosk. -Anat. Forsch. 18: 14.

STREETER, G.L. (1942). Developmental horizons in human embryos: Description of age group XI, 13 to 20 somites and age group XII, 21 to 29 somites. Contrib. Embryol. 30: 211-245.

STREETER, G.L. (1948). Developmental horizons in human embryos: Description of age groups $\mathrm{XV}, \mathrm{XVI}, \mathrm{XVII}$ and $\mathrm{XVIII}$, being the third issue of a survey of the Carnegie Collection. Contrib. Embryol. 32: 133-203.

STREETER, G.L. (1951). Developmental horizons in human embryos: Description of age groups XIX, XX, XXI, XXII and XXIII, being the fifth issue of a survey of the Carnegie Collection. Contrib. Embryol. 34: 165-196.

VALENTIN, G.G. (1835). Foetus. In Encyclopädisches Wörterbuch dermedicinischen Wissenschaften (Eds. D.W.H. Busch et al.), vol. 12. Veit, Berlin, pp. 355-389.

WAELSCH, S.G. (1992). The causal analysis of development in the past half century: A personal history. Development (supplement), 1-5.

WITSCHI, E. (1956). Proposals for an international agreement on normal stages in vertebrate embryology. XIV International Congress of Zoology, Copenhagen, 5-12 August 1953, Proceedings. Copenhagen, pp. 260-262.

Received: 15th June 2006 Reviewed by Referees: 27th July 2006 Modified by Authors and Accepted for Publication: 27th September 2006 Published Online: 7th December 2006 